\title{
AFEHANISTAN FORUM
}

EONTENTS

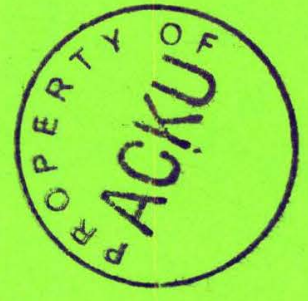

VDL. XdV

July 1986

ND. 4

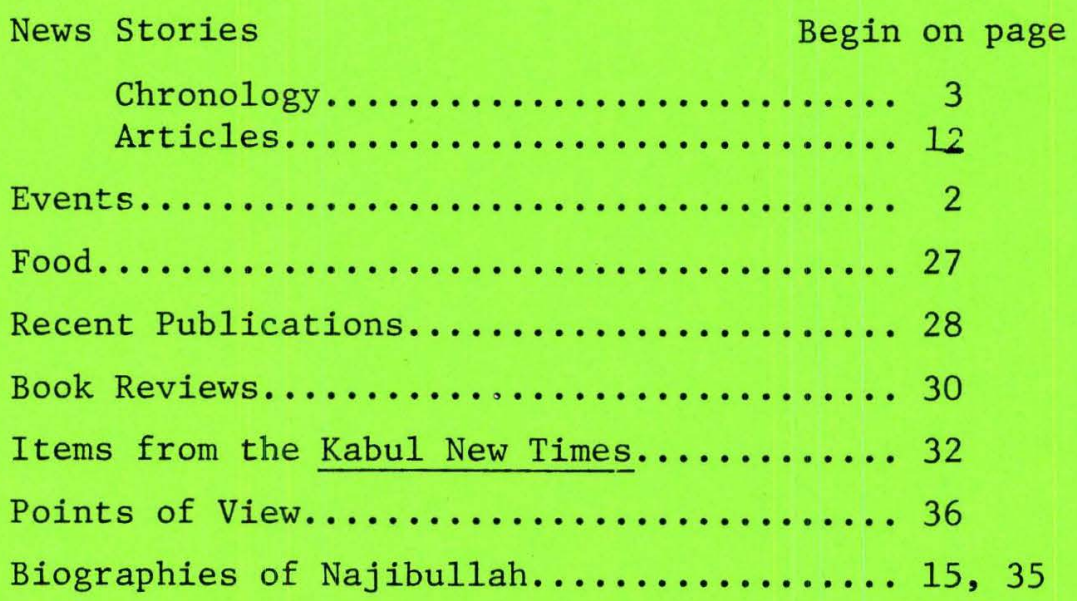

\section{AFEHANISTAN FORUA, INE. टDL EAST T15T 5TREET. ZK NEW YORK, NY LODZL}






ABBREVIATIONS USED

AICMB - Afghan Information Center Monthly Bulletin
AWSJ - Asian Wall Street Journal
BIA - Bakhtar Information Agency
CC - Central Committee
CSM - Christian Science Monitor
DRA - Democratic Republic of Afghanistan
DYOA - Democratic Youth Organization of Afghanistan
FEER - Far Eastern Economic Review
FRG - Federal Republic of Germany
IHT - International Herald Tribune
KNT - Kabul New Times
NFF - National Fatherland Front
NWFP - Northwest Frontier Province
NYT - New York Times
NYCT - New York City Tribune
PDPA - People's Democratic Party of Afghanistan
PSFO - Peace, Solidarity \& Friendship Organization
PT - Pakistan Times
RC - Revolutionary Council
RTV - Refugee Tent Village
SCMP - South China Morning Post
UNGA - United Nations General Assembly
UNHCR - United Nations High Commission for Refugees
WDOA - Women's Democratic Organization of Afghanistan
WSJ - Wall Street Journal

Line drawing from the 1982 Afghanistan Calendar of the Chicago Afghanistan Relief Committee.

Please send items for the AFGHANISTAN FORUM to The Afghanistan Forum, Inc.

201 East 71st Street, 2K

New York, NY 10021, USA

The opinions expressed in the FORUM are those of the parties \& publications involved and are not necessarily those of the Afghanistan FORUM. Listing of organizations does not necessarily imply endorsement.

Subscription rates: $\$ 20$ per year (US \& Canada) (Add $\$ 5$ for FORUM PAPERS)

6 issues/year

$\$ 24$ per year (foreign); airmail Europe - \$35; Asia $\$ 40$.

$\$ 35$ per year (institutions) (includes FORUM PAPERS) 
From the editor:

The change of leadership in Kabul brought Afghanistan briefly into the headlines - as did the Reagan Adriinistration's ambiguity over its relationship with the mujahideen - but Afghanistan remains the scene of one of the most unreported wars in recent history. In spite of the paucity of print, this issue is full of amazing analyses, conflicting reports, wishful writing and strange statistics. Incidents along the Pak-Af border are on the increase as are bomb blasts in Peshawar and environs; Diego Cordovez is still hopeful about the Geneva talks although he's about the only one that is; the "Stingers" seem to have gotten lost; the fighting goes on and on...

We thank all of you who sent items for this issue; keep the information coming. The deadline for the next issue is August 15.

We havn't received any abstracts lately. Remember, if you will be giving a paper or writing an article, we'd appreciate a half-page summary to give our readers the benefit of your wisdom.

Mary Ann Siegfried
Plus ça change...

plus ça même chose?

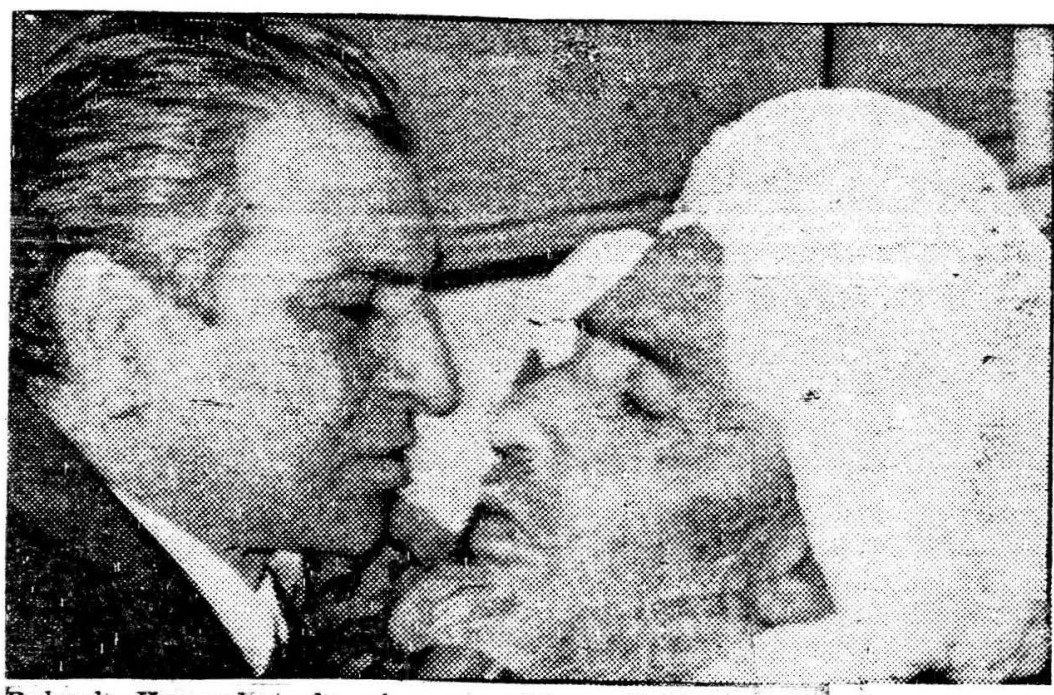

Babrak Karmal embracing an elder of Herat city DRA Foreign Affairs Bulletin

$$
10 / 82
$$

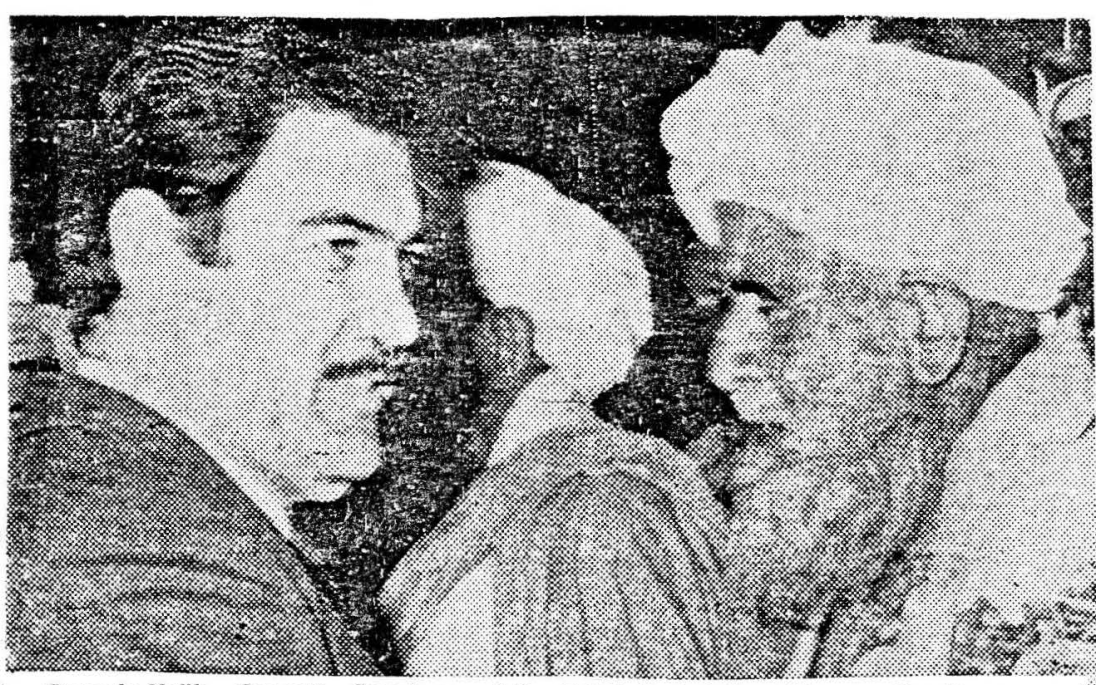

Coonrade Nasib, General Secretary of the PDPA Central Committee meeting the represent Ives of the mortidos peo ple of Logar province .

KNT $5 / 25 / 80$ 


\section{EVENTS}

"Understanding the Current Situation in Afghanistan" was the topic of a session at the American Council for the Study of Islamic Societies at Villanova U, May 23-24. Louis Dupree $\&$ Theodore Mataxis organized the pane1.

"The Sovietization of Afghanistan" was the topic of Nake Kamrany's contribution to an economic policy colloquium at $U$ of Southern California on $4 / 1$.

The 1987 Annual Meeting of the Association for Asian Studies will be held at the Boston Sheraton Hotel from April 10 to 12, 1987. The deadline for panel \& paper proposals is August 1, 1986. Drogram chairman for South Asia panels is David Lelyveld, Southern Asian Institute, Columbia University, New York, NY 10024. (212) 288-1300 ext. 280.

The Society for Afghan Artists presented the "Greatest Show of the Year" on 6/29 at Queensborough Community College, Bayside, NY.

"Conditions for a Political solution in Afghanistan," a seminar organized by the Afghanistan Int' 1 Bureau, was held at the National Assembly in Paris on June 6-7. Sibghatullah Mujadeddi represented the Islamic Alliance at the sessions. (The DRit foreign ministry protested to the French charge in Kabul over the start of a new activity hostile to Afghanistan.) CEREDAF, another French organization is plañning a fall conference on putcing the current Afghan situation in histurical perspective.

Afghanistan was the topic of a panel at a meeting of the Pakistan Students' Assn. at the $U$ of Maryland on $4 / 2$. Selig Harrison spoke on the proposed diplomatic solutions; Zalmay Khalilzad discussed present military strategies; Jon Anderson spoke on the role of tribal structure; \& Kaukab Siddique discussed the religious significance of the Afghan struggle.
AFGHAN ACTION COMMITTEES

To arouse public awareness of the Afghan issue, the North Carolina Federation of College Republicans adopted the following as its state-wide goal:

1) to strive for the formation of as many Afghanistan Action Committees (AAC) in as many regional colleges \& universities as possible. Similar to the bi-partisan support in the US House \& Senate for assistance to the Afghan people, the organizations are to be nonpartisan \& should include students from all political viewpoints...;

2) to support the Afghan freedom fighters as well as American military, social \& economic aid directed at bringing this conflict to an end;

3) to call for Soviet withdrawal from Afghanistan \& the return of Afghan refugees to their homeland from refugee settlements in Iran \& Pakistan.

Students are urged to form committees on other campuses.

\section{AUSTRIAN RELIEF COMMITTEE CALENDAR}

The Austrian Relief Committee plans to offer a $19 \overline{8} 7$ calendar featurring color photographs of Afghan children. Organizations interested in ordering copies in bulk should contact the ARC, F.O. Box 489 GPO, Peshawar, NNFP, Pakistan, by the end of July. Prices will be ca. $\$ 2$ for 50 - 1000 copies plus postage. (The ARC acct 非 is 284820712 in Grindlays Bank plc, P.O. Box 18, 35 Shahra-e-Quaid-eAzam. Peshawar Cantt, NWFP, Pakistan.)

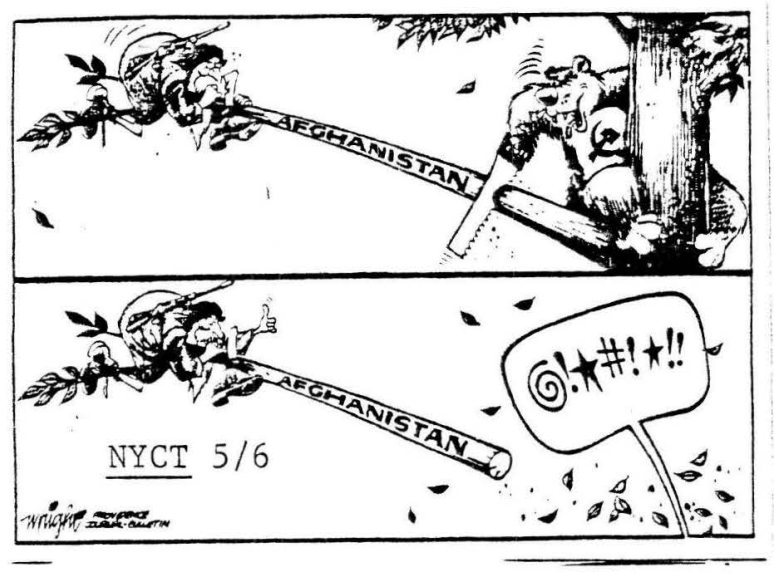




\section{EHRDNDLDGY}

4/14 - BIA - "Revolutionary Afghanistan is one of the victims of information imperialism \& that is why it knows negative impacts more than any other countries," said Moh'd Arif, Sec'y of the Afghan-British Friendship Society, in an address to the 2nd conference of the New Int'1 Information Order in Kabul. However, imperialist propaganda "is meager as it does not have a real base."

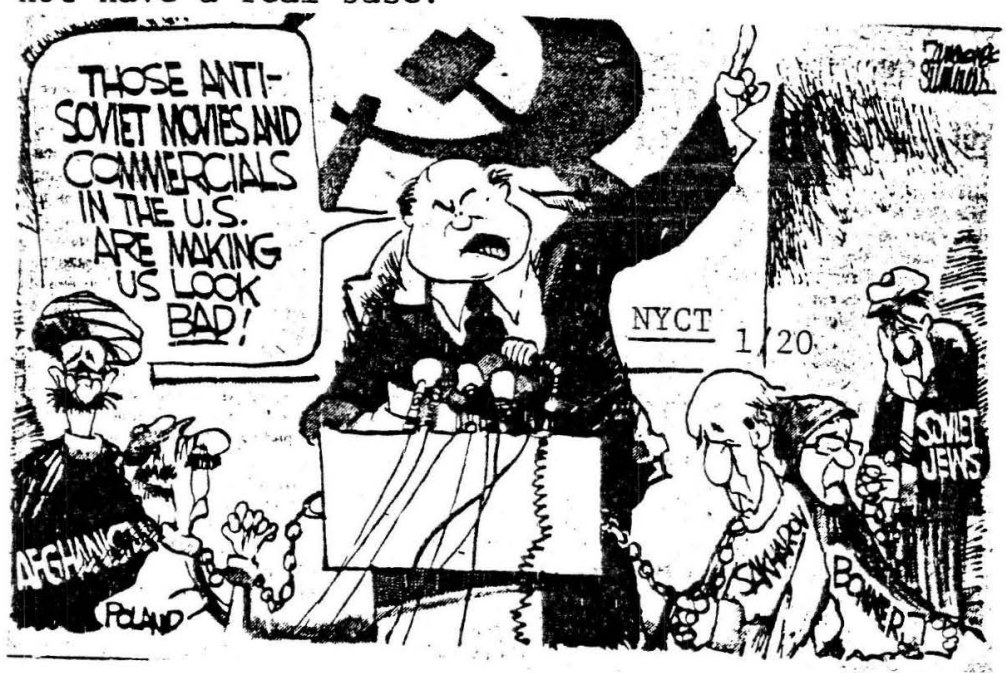

4/19 - BIA - In the last Afghan year, foreign trade circulation was $\$ 1359.7 \mathrm{~m}$. Trade with "hard currency areas such as the USA, Britain, FRG, Japan, France, Switzerland, Italy, Hong Kong, Singapore \& Thailand is almost normal" $\$ 394.7 \mathrm{~m}$ of which $\$ 130.4 \mathrm{~m}$ represented export items: karakul, dried fruit, raisins, sheep casings, medicinal herbs, carpets \& handicrafts. The private sector accounts for $42.2 \%$ of the total foreign trade. On 5/24, Bakhtar gave the foreign trade figure as $\$ 1,413 \mathrm{~m}$ of which $\$ 848 \mathrm{~m}$ was for imports $\& \$ 565 \mathrm{~m}$ exports, with the USSR's share in exports $8 / 5 \%$, in imports $5 / 2 \%$.

- PT - UN Special Representative Diero Corclovez met separately with the foreign ministers of Pakistan, the DRA \& Iran at the Non-Aligned Nations Coordinating Bureau meeting in Delhi to discuss the next round of Geneva talks. The Bureau retained its position on Afghanistan, calling for a political settlement of the problem based on the withdrawal of foreign troops.

4/20 - BIA - An agreement on legal cooperation was signed by the DRA \& Iraq.

4/21 - BIA - Sultan Ali Keshtmand left for a visit to the USSR accompanied by Sarwal Mangal, Pres. of the Planning Committee; Raz Moh'd Paktin, Minister of Power; Moh'd Aziz, Minister of
Light Industries \& Foodstuffs; Sayed Murtaza, Coordinator of the Council of Ministers; Abdul Tawab Zakayee, Dep. Min. of Foreign Affairs \& Abdul Baqi Samandri, Dep. Min. of Finance. On 4/23, Keshtmand signed an economic protocol with the USSR for 1986-1990.

4/22 - BIA - Keshtmand told Kremlin officials that ca. $45 \%$ of the DRA state budget revenues comes from projects built with Soviet assistance \& over $75 \%$ of the DRA's industrial products are produced in Soviet-built projects. However, he said that since the April Revolution human \& material losses have amounted to $\$ 1 b$. The joint communique issued at the end of the visit (4/24) stressed the need for a complete termination of armed \& other kinds of intervention from abroad in the DRA; the USSR reiterated its support for DRA efforts to defend its sovereignty.

4/24 - HK Standard - Afghanistan wants India to join Washington $\hat{x}$ Moscow as int' 1 guarantors of its independence if the UN talks succeed, according to the Press Trust of India which quoted Mahmood Baryalai. Baryalai also said that the US \& the USSR should join the UN talks.

- PT - Mujahideen attacked Shindand airport destroying a control room \& a helicopter; VOA reports that only military personnel are being treated in Kabul hospitals because of heavy casualties in battles around the country.

- Benazir Bhutto told a gathering in Peshawar that she wanted the return of Afghan refugees with honor in a political settlement leading to the withdrawal of Soviet troops. She said that the refugees would not be thrown out of Pakistan if she comes to power, but that their presence was a "destabilizing factor \& a tremendous problem." 
4/26 - BIA - Elections for people's representatives to the local organs of state power began in Kunar Province.

- Defense Minister Nazar Moh'd thanked the DRA armed forces \& "the inhabitants of Khosit Grand Dist. for their successes in eliminating the bandits in several areas...Gifts, letters of merit \& cash prizes were also awarded to a number of soldiers $\&$ officers..."

4/27 - The DRA \& the USSR signed contracts for equipment to build the Mazar-i-Sharif, Jarikduk, USSR, Kunduz \& Khulm-Puli-Khumri power lines; a feasibility study for the "Sarobi-2 cascade of hydro-electric power stations" \& for planning a power line over the Panj River.

4/29 - BIA - The DRA protested to Iran over Iranian anti-DRA propaganda, specifically an interview given by "Sheikh Husaini \& Nasrullah inonsoor linked with the counter-revolutionary organizations of Iasr \& Hezb-e-Harakat-e-Enqelabe-Islami Afghanistan" attacking the upcoming Geneva talks. The DRA demands that Iran cease its anti-DRA propaganda \& activities.

- In Jalalabad, Bayazid Roshan U, established after the revolution, now has 5 faculties \& ca. 1,000 students.

- PT - The Soviets have restricted the movements of Interior Minister Syed Moh'd Gulabzai, a Khalqi. Several other Khalqi officials have been removed in the past few months \& Parchamis are being recruited for the vacancies. The night curfew in Kabul is from $10 \mathrm{p} \cdot \mathrm{m}$. to $4 \mathrm{a} . \mathrm{m}$. \& some DRA cities now have an 8-hour curfew.

5/1 - BIA - Babrak returned from Moscow \& was welcomed along the airport route by crowds chanting slogans \& throwing flowers.

$5 / 3$ - NYT - Casualty figures in the battle for Zhawar, according to the mujahideen: 125 dead, 220 wounded; DRA-Soviet losses, 280 killed

300 captured. (See below \& 5/5)

$5 / 4$ - HK Standard - The battle of Zhavar:

Moscow: Afghan soldiers aided by Soviet troops killed 2,000 rebels and wounded 4,000 in destroying a major guerilla stronghold in southeastern Afghanistan, Soviet newspaper reports said:

The three-week battle at Zhawar, the guerillas' largest base, ended in late April. Rebel sources in Pakistan have acknowledged heavy losses against Soviet and Afghan air force planes, helicopters and ground troops.

Two newspapers carried long articles on Wednesday and Thursday about the batthe.

Izvestia's story devoted to Soviet helicepter pilots ferrying Alhgan soldiers into the battie zone. The second story, in the Defence Ministry organ Krasnaya Zrezda (Red Star), focused on technical details and statistics, and did not mention Soviet troops at at

The Krasnaya Zvezda described the Zhawar stronghold as being built with Western help..-

The paper also said the head of the Zhawar training centre, identified as Yar Mohammad, was killed, along with a deputy rebel leader it called Khan Mohammad, and three Western European advisers whose identity had not been established. - AP
5/4 - BIA announced the changing of the guard in Kabul. (See $5 / 5$, $5 / 7,5 / 8,5 / 12,6 / 8 \&$ p. .) - PT - Former US UN Ambassador Jeane Kirkpatrick at a hearing before the Congressional Task

Force on Afghanistan said she found found it "incom prenensible" that the Unted States maintained diplomat c relations with what the Afghan "puppet regime" in Kabul.

"I see no advantage whatsoever in the continued main tenance of our Embassy which serves very little purpose." ...

Kirkpatrick crit'cised provision's of a U.N.-sponsored draft agreement between Af. ghanistan and Pakistan that she sa:d would exclude the Mujah deen, who have battled Sovet and Afghan troops since eariy 1980.

She also blasted any agreement that would make a w.thdrawal of Soviet troops conungent on the prior agree. ment of the Uni ed States to end miltary support for the Mujahideen.

"If is inconce vable to me trat the American Government should provide such guarantees of tyranny. It would obviousiy be a vio.a. tion of our principles and our pol.c'es," Kirkpatrick sa'd.

But she went on to say that she had "every confidence that the American gov. ermment will refuse such an agreement and withdraw any such guarantees."

Senator Gordon Humphrey, a New Hampsh re Republicin and co-Chairman of the ronet. told Kirkpatrick he was less confident that Washingt:r] would repudiate what he termed a "sell-out". of he Mujahideen.

"I'm frankly very uneasy $\mathrm{c} n$ that score," he sa.d. "I'm not sure we're in a posicion to withdraw our guarantes." Senator Bill Brad!ey a New Jersey Democrat agreed.

"America must refuse to guarantee any negot'a'ed settlement to wh:ch the leg!timate represen arives of ine Afghan people are not a party or which calls for Amer can non-ntervention as a prerequisite for Soviet withdrawal from Afghan stan," he told the hearing.-Reuter. 
5/5 - NYT - Tass announced that Babrak Karmal, $5 \overline{7,}$ resigned as Gen'l Sec'y of the PDPA for health reasons. He was replaced by 39year-old Najibullah, the former Khad chief. (See p. 35 for speeches.)

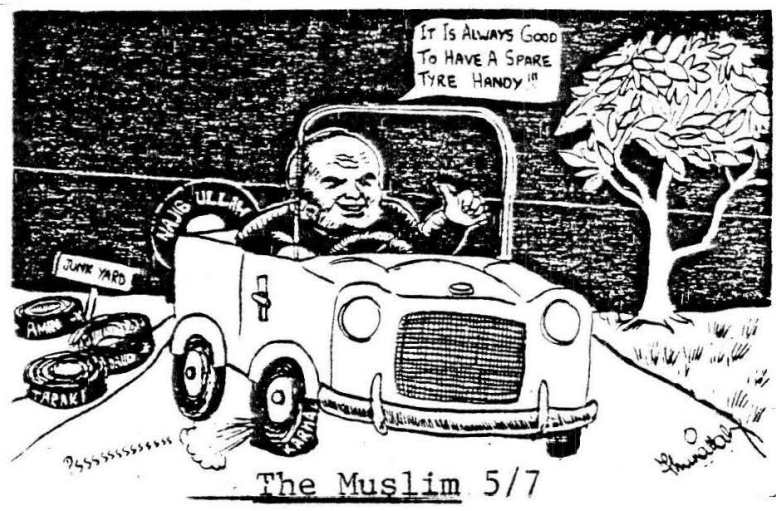

5/5 - HK Standard - Communist troops have launched an al1-out siege at Kandahar; guerrillas report that the CIA delivered some Swiss-made Oerlikon anti-aircraft cannons. - BIA - "Combing operations at Zhawara in Khost revealed a vehicle repair shop, a hospital \& pharmacy, a prison "for hostages," \& "a villa for the leaders of the bands \& foreign instructors \& a restaurant with a bar" as well as weapons, clothing \& food.

5/6 - HK Standard: Afghan Communist Party chief Na. jibullah is nicknamed by many of his countrymen as "the bull" for his power and ruthlessness as secret police and espionage chief.

- NYI - The 7 th round of peace talks ve gan yesterday in Geneva. AP reported in the HK Standard (5/4) that Pakistan is pressing for a Soviet troop pullout within a few months; Afghanistan is aiming at a schedule that would run into the early 1990s.

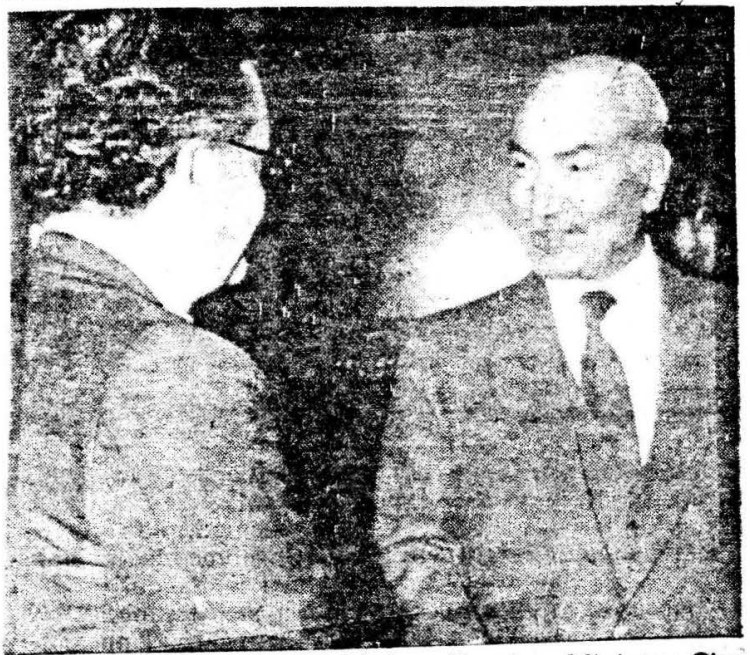

Mr Cordovez greets Afghan Foreign Minister Sha Mohamed Dost (right) at the start of the peace talks. - Reuter picture.
5/7 - PT - Tehran Radio reported that gunfire was heard in Kabul's presidential palace after Babrak's resignation. Kabul airport was reported closed for 2 hours to allow Babrak to depart for some unknown destination. - SCMP - A party crisis?
Islamabad: Soviet tanks surrounded key Government buildings, blocked off Afghan Army barracks and trained their cannons on Kabul from surrounding hills during a three-day meeting to pick a new Communist Party leader last weekend, Western diplomats said yesterday. at demonstrations by women and youths supporting President Babrak Karmal were broken up by security police during and after the meeting attended by Moscow's ambassador.

The tense party Central Committee session chose the former security chief, General Najibullah, 39, as the new party leader on the eve of renewed Afghan peace talks in Geneva.

Mr Karmal, while remaining President, resigned officially as party leader for health reasons.

Mr Zahoor Razemjo, Kabul party boss and Politburo member, was reported to have been beaten up by Karmal supporters when he ordered posters of the President.
The diplomats said sever: to be torn down.

The diplomats said most Afghan troops manning extensive road blocks in the city centre were unarmed, apparently to stem any possible revolt.

The Interior Ministry, led by Gen Najibullah's rival General Sayed Mohammad et tanks:

The diptơmats said secret police broke up a women's protest near the presidential palace on Friday morning at the start of the meeting in the heavily guarded complex which also houses the Central Committee building.

They said it may have been organised by Mrs Anahita Ratebzad. a Politburn member, head of the women's organisation and friend of Mr Karmal. She lives near the alace.

Russian paratroopers also took up positions around other Soviet installations like their housing project in Mkrorayon, hospital in Shari-Nau and sprawling embassy in western Kabul, the diplomats said. Gulabzoi, was ringed by Sovi-

5/8 - BIA - Comrade Najib, meeting with tribal elders, said "the Pushtoon nationality as a big brother should bear a high sense of responsibility alongside the brother nationalities - Tajik, Hazara, Uzbek, Turkman, Balooch, Nooristani \& Pashai for the fulfillment of the grave tasks facing the party \& state."

- At today's politburo session the work of the legal institutions was examined. Addressing the group were Babrak Karmal, Sultan Ali Keshtmand, Saleh Moh'd Zerai, Noor Ahmad Noor, Dr. Anahita Ratebzad, Moh'd Aslam Watanjar, Moh'd Rafi, Mahmood Baryalai, Gen. Nazir Moh'd, Suleiman Laeq, Zohor Razemjo, Gen Moh'd Yasin Sadiqi, Mir Saheb Karwal \& Niaz Momand as well as Comrade Najib.

- Working hours during Ramazan, which starts tomorrow, will be from $7 \mathrm{a} . \mathrm{m}$. to 1 p.m.. Prayers \& Koran readings will be held in mosques thruout the DRA. 
5/8 - PT - The British Financial Times commented that Babrak's removal before the Geneva talks might be a sign that Moscow wants a political settlement $\&$ that Najibullah's appointment is a guarantee that there will be a friendly gov't in Kabul. The Times stated that Najibullah might be able to establish a gov't which would not need such massive Soviet support. Kremlin policy makers were apparently unhappy with Babrak's unwillingness to give his full support to the plan for a Soviet troop withdrawal.

- Voice of Germany reported that no newspapers were published in Kabul the last 5 days \& that telephone links with the outside world were cut off. Babrak's "halffather" is believed to have been killed during a tumultuous session of the PDPA CC.

$5 / 9$ - NYT - Najibullah ordered a drive against increasing corruption in the DRA.

5/10 - BIA - The CC of the Fedayan Organization in Iran sent a congratulatory message to Comrade Najib on his election as Gen'1 Sec'y of the PDPA CC.

- The DRA accused Iran of helping counterrevolutionary forces attack Kazi village in Herat. 12 were killed, 2 wounded \& 1 captured \& the DRA asked for compensation.

5/11 - BIA - The Bakhtar Afghan Airlines operates weekly flights from Kabul to Tashkent, Moscow, Prague, Delhi, Amritsar \& Dubai. The airline has 2 Boeing 727s, 2 Antonov 26s, 2 Antonov 24s, 2 Yak 40s \& 1 Twin Otter. New airports are planned for Laghman, Takhar, Kunar \& Logar provinces.

$5 / 12$ - BIA - During the past 2 years over 4,000 Kabul school graduates have volunteered for the armed forces \& 5,000 have offered to work in the coal mines. - "There is hustle \& bustle In Khost's bazaars \& people are continuing their normal life," according to a Haqiqat-eEnqalab-e-Saur reporter touring the area. "The people of Khost as all people of Afghanistan defend the April Revolution \& giving to rebels tooth breaking response." - Kabul Univ. is gearing up to celebrate its 40th anniversary. It has cooperation agreements with Tajik \& Tashkent Univs., Humboldt $U$ in Berlin, Sofia U in Bulgaria $\&$ is negotiating an agreement with Brno $U$ in Czechoslovakia.

5/12 - LA Times - Babrak supporters, mostly students, have held at least 8 demonstrations in Kabul protesting Najibullah's appointment. On 5/19 the Times says that the most serious clash between Babrak \& Najib factions took place in Kandahar where army factions used rocket launchers against each other.

\section{$5 / 13$ - SCMP -}

Islamabad: The children of Kabul's top families have been active in protests against the demotion of former Afghan communist leader $\mathrm{Mr}$. Babrak Karmal, reports from Western dipiomats indicated yesterday.

Students at the capital's elite Westernised high schools led most of at least eight rare demonstrations backing $\mathbf{M r}$ Karmal, who was replaced as party chief eight days ago, the reports said.

And they added that, in a surprise twist for a Muslim society, girl students were as active as boys in the protests.

- BIA . Comracie ITa terview, said that
income has already ceeded the prerevolutionary level, that ca. 320,000 "landless \& land hungry families have been provided with more than 340,000 jeribs of land free..." He put PDPA membership at 155,000, NFF membership at 760,000 and "nearly 200 bands comprising over 30,000 hirelings trained \& armed abroad were routed in the country in 1985 alone... the warcraft of our men \& officers is developing \& their morale is growing stronger."

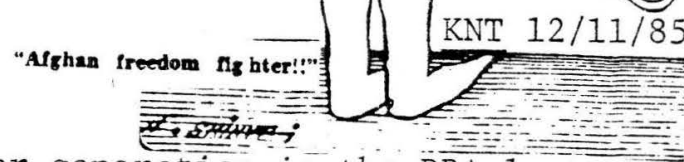
- Power generation in the DRA last year was $764 \mathrm{~m} \mathrm{kwh}$; this year it will go to $885 \mathrm{~m} \mathrm{kwh}$; by 1991 - $1750 \mathrm{~m} \mathrm{kwh}$. 
5/13 - PT - Former British pop singer Cat Stevens, who spurned stardom to embrace Islam in 1977, is considering making a comeback to raise money for Afghan refugees. He launched Muslim Aid in February to raise funds for refugees.

- IHT - Resistance groups have reopened some of the supply routes which were cut off in last month's offensives. They are reestablishing their base at Jawar: however,

equipment, had assumed a symbol-

Several resistance officials ic importance for the rebels. agreed that the Mujahidin may "After holding it for seven years, have tried to hold the base at Jawar the Mujahidin began thinking too long, exposing themselves to Jawar was impregnable," said Moheavy air and artillery strikes hammad Es'Haq, a political officer against which they had no defense. of the Jamiat-i Islami party.

Jawar, an elaborate base dug "But no matter how strong we into the sides of a canyon and are; we are still guerrillas, and we equipped with shops for repairing should not try to hold territory or captured tanks and other heavy fixed bases like this," he said. "Now, I think, we will remain more mobile"

$5 / 14$ - PT - Gen. Najibullah has pledged his gov't to strive for an early settlement to the Afghan problem, according to Tass.

- BIA - The DRA Artists Union is kolding a political song contest. vinners will divide Afs 300,000 in prize money.

5/15 - BIA - Sultan Ali Keshtmand told the Economic Consultative Council (a group for formulating trade proposals) that the DRA will draft a new law on private investment to stimulate private enterprise and to harmonize the interests of the state \& the private sector.

- PT - In Moscow Anatoly Dobrynin said that the USSR wanted to bring its troops home from Afghanistan in the near future. - 24 Afghans arrived in the US for reconstructive surgery. Their visit is sponsored by Heal the Children, Committee for a Free Afghanistan, Free Afghanistan Alliance, Americares \& Texas Congressman Charles Wilson. $5 / 16$ - SCMP - New troika: nist groups associated with

Islamabad: Afghan Cơnmunist Party chief Mr Najibullah yesterday announced a new collective leadership, which includes him, President Babrak Karmal and Prime Minister Sultan Ali Kishtmand...

He said Mŕ Karmal, as head of the Revolutionary Council and its presidium, would be concerned with strengthening "state power organs" with the support of "national patriotic forces."

State party organs are apparently organisations like the armed forces while patri-
$5 / 18$ - BIA - A protocol for scientific \& cultural cooperation for 1986-90 was concluded between the DRA \& Mongolia. It covers "education, art, culture, public health, physical training \& mass media."

- The National Museum of Afghanistan now owns "over 1,000 historical relics $\&$ ancient works," $10 \%$ of which are on display.

- NYT \& SCMP - The Pakistani Air Force shot down an Afghan MiG-21, damaged a second \& chased off 2 others. The incident occurred 10 miles from the Afghan border near Parachinar. (See 5/21)

$5 / 19$ - BIA - The Ist Museum of Youth will. be inaugurated in Kabul on the 10th anniversary of the founding of the DYOA at the end of May. Other anniversary events will include concerts \& TV programs. Youth will decorate Kabul city \& some frontier provinces with posters, slogans \& big painted tableaux.

- "Lack of foodstuffs is not noticed in Kabul." 25 - 30,000 tons of are in the 20 markets in the city. Prices fluctuate according to the season.

$5 / 21$ - HK Standard - Nestern sources report that advanced Soviet aircraft MiG-25 jets, MiG-23s \& SU-22s are being used in eastern Afghanistan. - BIA - Pakistan's claim that it attacked 2 DRA planes over Parachinar (see 5/18) is groundless. On 5/17, two DRA fighter planes were damaged "during an internal operation conducted against the counter-revolution." - Moh'd Aziz Negahban is Minister of Civil Aviation in the DRA.

- - The DRA State Culture Committee has "created the nucleus of a new department responsible for the growth \& expansion of Afghan folklore," according to Culture Dept. Pres. Azim Lemar.

$5 / 22$ - BIA - The Politburo instructed the "concerned authorities to prepare $\&$ examine the necessary documents for the just drafting of youth to the military service regardless of their social, family, party or state status." (cee $5 / 29$ \& 6/1.) 
5/23 - PT - Pakistan \& the DRA have

"reached a stage of complete incompatibility on the key issue of evolving ground rules for a discussion on the time frame for the withdrawal of Soviet troops from Afghanistan as the 7 th round of proximity talks slowly moves to an almost impossible position."

- A UN panel recommended the renewal of the mandate of the special rapporteur for the human rights situation in Afghanistan - 37 to 7 with 5 abstentions.

5/24 - NYT - The 7th round of Geneva talks was suspended yesterday. The DRA $\&$ Pakistan will resume negotiations on $7 / 30$ after consulting with their gov'ts. - HK Standard - Heavy fighting has been reported around Jaji as the Soviets continue to try to close guerrilla supply routes. 40 mujahideen were killed \& 45 wounded; Soviet-DRA losses were 96 dead \& 130 wounded.

- PT - Soviet-DRA troops have abruptly ended offensives in the Haji (sic) area of Paktia.

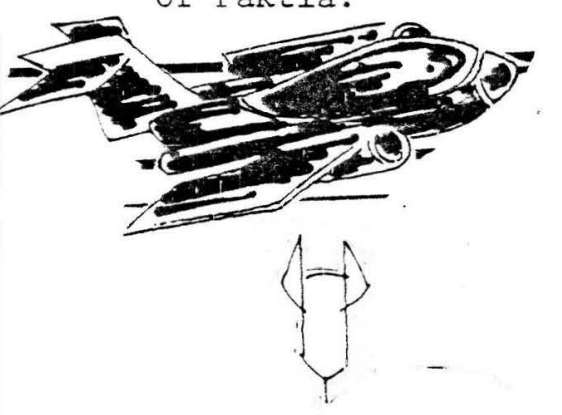

- BIA - Currently the state subsidy to gov't employees for flour is $71 \%$. - The UN is helping the DRA develop solar energy for use in cooking \& heating water.

\section{$5 / 25$ - BIA - The DRA} has allocated over Afs $125 \mathrm{~m}$ for haj pilgrimage subsidies. This year over 5,000 Afghans expect to go to Mecca. - PT - Kabul has been put under "military control" because of clashes between party factions. Agency Afghan Press also reports that the Soviers are poisoning water tanks \& fountains in Paktia. - BIA - Electtions began in Samangan Prov. ists. ..

\section{5/28 - IHT - Najib \& corruption:}

General Najibullah has railed against corruption and sloppy work at meetings of political commissars, Interior Ministry militiamen, border tribes and party activ-

He was expected to shuffle the cabinet soon, bringing more mem-

bers of ethnic minorities into high positions to promote a "divide and rule" nationalities policy that Afghan exiles say Moscow favors.

The diplomats also said that Khad was stepping up pressure on two Western companies Hoechst and Brown, Boveri - in a possible attempt to force foreign technicians to leave.

5/29 - BIA - Babrak chaired the RC Presidium meeting today. The military amnesty decree was approved. Deserters $\&$ those who have not done their military service (owirig to enemy propaganda) will not be punished if they turn themselves in within 6 months. Armed Forces Day will be celebrated 8/19 which is also Inderendence Day. - Imperialist boycotts \& bandit obstacles have produced some problems in supplying commodities, particularly consumer goods. However, the DRA has taken effective measures to prevent shortages $\&$ rising prices. (See 5/19)

- SCMP - Germans train Afghan reporters:

Bonn: A group of Afghan rebels completed training in West Germany as television reporters yesterday saying they would return home to wage war on Russian troops with "cameras as well as Kalashnikovs."

The 20 rebels were the first of a planned 60 to complete four-week courses as cameramen under a private scheme initiated by conservative member of parliament $\mathrm{Mr}$ Juergen Todenhoefer, who said he believed it was the first of its kind.

"The aim of this action .... is to break through the wall of silence erected around Afghanistan by the Soviet Union," the Christian Democratic politician told a press conference.

He accused Moscow of genocide during its six-yearold invasion of Afghanistan and said film coverage by rebels could increase public pressure on Russian forces to end what he termed a "forgotten war."

Mr Aminullah Wardak, one of four rebel commanders who took part in the course, said the films would "heip counter propaganda that the Russians are helping the Afghan people."

"We have fought the Russians with Kalashnikovs
(Kussian-made assault rifles). Now we will fight them with cameras as well," Mr Wardak said.

The Afghan Government has rarely allowed Western reporters to visit Afghanistan since the Russian invasion.

Dozens of camera tearns have entered illegally for spells with rebel units but $\mathrm{Mr}$ Wardak said they were often unable to go to towns and villages that had been bombed by Russian forces.

$\mathrm{Mr}$ Todenhoefer launched his project in December to coincide with the sixth anniversary of the Russian invasion and said yesterday it was being financed entirely from three million marks (about HK\$10.1 million) in donations from the West German public.

He has twice entered Afghanistan with rebels, prompting an official protest to West Germany from the Kabul Government.

$\mathrm{Mr}$ Todenhoefer said the rebel reporters would be equipped with video cameras specially shock-proofed for combat conditions.

He said the scheme's organisers were trying to arrange for their work eventually to be made available to Western media.

-Reuter. 
$6 / 1$ - BIA - Comrade Najib said the state will resolve the nomads' problems. They will be given permanent settlement, pastures \& water; markets for their goods will be sought \& the problem of educating their sons will be tackled. 8 nomad schools have already been established in Herat. "The state of the DRA is determined... to put an end to the plight of the nomads wandering from 1 country \& 1 province to another" and to enable "them to live in free Afghanistan as happy $\&$ prosper ous people."

- Elections began in Fariab Province. - Sultan Ali Keshtmand visited the Interior Ministry to see about eliminating "shortages" \& improving supply systems. - PT - Moh'd Ishaq, political officer of Jamiat Islami, denied that his group had received \& used Stingers from the US. The Afghan-American Education Fund reported that 200 Stingers had been delivered to the mujahideen \& that of 12 fired, 11 missed their targets.

- $B B C$ reporting on the military amnesty decree in the DRA, said that the new draft law says that 40-year-olds can be summoned back to the army. Deserters already caught whose cases have not yet come to trial will not be punished but they will have to do a 2-year stint in either the army, police or national security forces. (See 5/29)

$6 / 2$ - HK Standard - A Soviet firing squad reportedly executed 7 Parchamis who took part in the pro-Babrak demonstrations on 5/6. 20 others were arrested.

- PT - DRA Brig. Gen. Mir Alam Khan, 40, of Ghazni, defected to Pakistan. He said that 40 DPA aircraft were damaged by mujahideen last year \& 40 others destroyed. He also reported that all Soviet aircraft have engine coolers so that heat-seeking rockets cannot follow them.

- A resolution is to be presented to the European Parliament calling for the recognition of the Islamic Alliance as the official representatives of the Afghan people. The resolution also calls for the withdrawal of Soviet troops, freeing of political prisoners, the admission of the Int' 1 Red Cross to the DRA \& denounces the use of chemical weapons \& the systematic destruction of villages in Afghanistan. The main objective of the resolution is to get the mujahideen included in the Geneva talks - along with the USSR,
$6 / 4$ - PT - Najibullah called on all Afghan refugees to return home for a "national reconciliation." He said they had left the DRA because of Hafizullah Amin's cruelty \& that the regime was responsible for the plight of the Afghans but that his regime wanted to help them.

6/4 - BIA - The Afghan Nichi Company, set up in 1982, promotes Japan-Afghan trade. Licorice root is the biggest DRA seller in Japan.

$6 / 5$ - PT - VOA reports that a DRA deputy security minister, identified only as Nabi, was killed near Kandahar when his jeep hit a mine.

- BIA - The KNT puts the "peasant population" of the DRA at $3.6 \mathrm{~m}$.

- The Politburo met today "in an atmosphere of democratic collective work." It was noted that an "ever-greater number of youth" are joining the armed forces - a "brilliant demonstration" of their "patriotic \& revolutionary awareness."

$6 / 7$ - $\underline{P T}$ - A number of Afghan refugees applied for political asylum at Amsterdam's Schiphol airport. They arrived with false papers on a Turkish airline flight from Istanbul.

- BIA - The DRA will import 700 tons of chicken, 100 tons of butter \& 20 tons of cheese this year. Cold storage facilities are planned for Hairatan \& Kabul.

- A new decree releases prisoners who have only 6 months left to serve. Exempted are murders, embezzlers (of over Afs 10,000), terrorists \& counter-revolutionary collaborators.

- DRA planners are faced with difficulties in national economic planning: "Socio-economic development planning in the DRA does not cover all the spheres of the national economy...Over $80 \%$ of the gross domestic products produced in the private sector are not included in the plan.." The state "guides" the private sector only by fixing the prices of goods - so state plans cover only $20 \%$ of the GNP.

- Babrak addressed the nation on radio \& TV on the eve of eid marking the end of Ramazan.




6/8 - PT - PDPA Sec'y Najibuliak was reported wounded on $6 / 2$ during a clash between his \& Babrak's supporters. The student demonstrations against Najib were supposedly organized by $\mathrm{Dr}$ Anahita Ratebzad (who was on her way to Sofia but turned back when she heard of Babrak's ouster). (See 6/9.) - Radio Beijing reports that some Afghan border provinces are being bombarded from inside the USSR.

6/9 - BIA - The Bakhtar political observer writes: "The Chinese News Agency Xinhua has reported...that Comrade Najib...has allegedly been wounded in the course of some 'conflict' which took place in Kabul. This information is a pure lie... Xinhua refers to some Afghan Press Agency. There is only 1 news agency in the DRA, namely Bakhtar Information Agency (BIA), which, of course, has not \& could not release any such news..."

$6 / 12$ - PT - A DRA military buildup has begun in Jalalabad.

- In an editorial on the frequent bomb blasts around Peshawar, the PT states that a number of Kabul secret agents have been arrested carrying explosives confirming that what is happening is fallout from the Afghan crisis. The editorial calls for an extensive system of vigilance to counter the sabotage.

$6 / 15$ - Afghan News - William Nelson writes that the Soviet Defense Ministry has proposed two alternatives for the Afghan stalemate: 1) "Soviet forces should be permitted to invade the Northwest province of Pakistan for 2 weeks..." If 1 is rejected, Soviet troops will withdraw with a face-saving political settlement to be pursued.


'In the heroic struggle against imperialist aggression, our glorious Soviet radioactivity was invited across neighboring European borders today ...
6/17 - NYT - In recent months bombs have exploded all over Peshawar, derailed the Khyber Mail express train, killed \& wounded dozens of people.

- A delegation led by Burhanuddin Rabbani, current spokesman for the Islamic Alliance of Mujahideen, met with Pres. Reagan to request diplomatic recognition. Reagan declined but voiced an "unshakeable commitment" to the resistance.

it was evident from comments by the Afghan rebels and by Larry Speakes, the White House spokesman, that tensions had developed. They stem from the Americans' continued recognition of the Afghan Government, their backing for United Nations-sponsored peace talks without rebel participation, and Washington's failure to provide advanced weapons to the rebels, including Stinger shoulder-fired antiaircraft missiles.

\section{$6 / 18-$ NYH -}

The Islamic

Alliance split

over the question
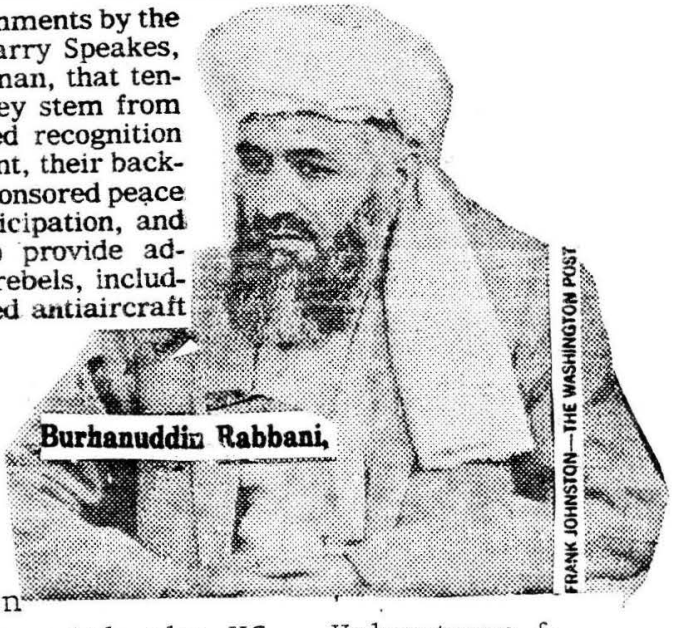

of identification with the US. Hekmatyar \& Saiaf, in Islamabad, said that Rabbani's trip to Washington had not been approved by the Alliance. Others said a visit-vote was taken \& the trip approved by 5 to 2 . The Afghan News of $6 / 15$ promises that "by the end of June the exile gov't of Afghanistan officially will be introduced to the world."

- A US Administration official said there was a possibility that the US would extend diplomatic recognition if they "acquired more of the attributes of a gov't."

- Washington Post - Bernard Weintraub writes that Afghan negotiators have mentioned a specific timetable in the Geneva talks "but that the proposal is being portrayed as unrealis-

tic." While Pakistani and U.S. diplomats roundly reject a reported Afghan proposal of a four-year timetable for the pullout of Soviet forces from Afghanistan under a comprehensive settlement, there are indications of some emerging differences between them on the continuing guerrilla war. . . . U.S. calculations indicate Moscow could pull its forces out in three to four months. Anything longer than that is viewed as being difficult to sell to the guerrillas.

"The Russians seem to think we can control the guerrilla forces, turning them on or off at will, but we can't exercise that kind of control," one U.S. official long familiar with the problem said. 
6/18 - NYT - Arthur Bonner writes that an increasing number of Afghans are cultivating poppies to raise money for the war effort.

Daud Khan, a young and energetic commander at the northern end of a string of villages known collectively as Deh Rawod, told of the advantages of cultivating opium: a ready market, no storage problems and easy transport.

"A farmer does not worry about selling his opium," he said. "Dealers come from Iran with money in their hands. If a farmer thinks he can get a better price at the border, he can hire a camel for the trip."

He said that the price for opium in Iran was much higher than in Pakistan and that the route to Iran was safer.

"There are no Government or Russian posts in the deserts to the west, while the route south to Pakistan passes through all the fighting around Kandahar," he said.

Farmers and dealers transporting the opium "go with four or five camels by secret routes, traveling at night," he said, adding that "they have their own guns and they hire" Afghan rebel soldiers "as extra guards."

"It is not the Russians they worry about," he said, smiling broadly. "It is robbers who are Afghans."

\section{6/19 - NYT - Leslie Gelb ex- plains it a11: \\ President}

Reagan told Congressional intelligence com committees around the New program of military aid to the Afghan rebels was aimed at removing Soviet forces from Afghanistan "by all means available," according to Administration officials.

Officials said in interviews today hat it was recognized at the time that the "all means available" language the "all means ambiguous. But they said such prewentations to the committees were normally in broad strokes.

This particular presentation, made in late 1985 or eariy 1986 , was in the form of either a written memorandum or an oral briefing, and the ambiguous language served two purposes, officials said. It provided justification for supplying more and better arms to the rebels, and it signaled to those in Congress who wanted to do more that $\mathrm{Mr}$. Reagan was on their side.

ther officials said the presentation, based on a Presidential decision of April 1985, was being interpreted more Ambitiously by some people in the White House, the Pentagon and the Central Intelligence Agency.

\section{Maneuvering by Conservatives}

These interpretations, in turn, are said to be at the root of maneuvering over whether to extend diplomatic recognition to the Afghan rebels and to recognitions with the Afghan Governcut re

The officials said that recognition The oficials effect of undercutting could have the effect of undercutting United Nations-sponsored talks between Pakistan and the Afghan Government aimed at a nonaligned Af- ghanistan, Afghan self-determination, the return of refugees from Pakistan and the withdrawal of Soviet forces.

Larry Speakes, the White House spokesman, reacted sharply today to reports that thought was being given to recognizing the rebels. He reiterated what he said Monday, that this would be "premature."

Charles E. Redman, a State Department spokesman, in endorsing the United Nations talks, said, "We have consistently supported the position and principies of the United Nations in bringing an end to this conflict."

*No Stingers Reached Rebels

Meanwhile, Administration officials confirmed that Stinger shoulder-fired antiaircraft missiles reportedly sent to the rebels two months ago had never reached them. Several days ago, rebel leaders visiting here said the missiles had never even been promised to them.

Officials said that a decision by Mr. Reagan in February or March to send. the Stingers still stood and that the delay was occasioned by "temporary" problems such as the need to train the rebels, the need for assurances that the missiles would not be diverted to terrorists, and the need to make Pakistan's role in the delivery less visible.

A Pentagon official said there was also a problem of "other countries and groups who have asked for Stingers and been denied them saying to us, 'If the Afghan rebels get them, we are entitled, too.' "'

One Administration official said there was a chance that the Afghan rebels would never get Stingers.

"Temporary problems have a way of becoming permanent," he said. "

The issue of supplying Stingers to the Afghan rebels has been a matter of debate within the Administration for some time. For about a year, the United States has been supplying the rebels with Soviet-made SAM-7 portable antiaircraft missiles, which are said to perform unevenly.

Today officials said that under the decision earlier this year to send Sting ers, Mr. Reagan intended to supply 150 Stinger launchers with 300 missiles. This is less than the numbers hinted at by Administration officials at the time.

The officials also said that Mr. Reagan chose the original Stinger rather than the newer Stinger Post. The original Stinger is said to have problems in that helicopter gunships can deflect its heat-seeking guidance system by firing a flare. The Stinger Post is said to be able to overcome such defenses. ..

According to officials, a Government study in April 1985 found that the Soviet forces were gradually wearing down the rebels, leading $\mathrm{Mr}$. Reagan to broaden the objectives of the covert aid program. He issued a document, $\mathrm{Na}$ tional Security Decision Directive 166 that called for driving Soviet forces from Afghanistan "by all means available."

The directive, in turn, became the basis of the presentation to Congress, and the Administration also informed the intelugence committees of its intention to provide Stingers.

Some legislators resisted on the ground that the missiles might fall into terrorist hands and might provoke an increase in Soviet activity.

But the hesitations are said to have been overcome by a coalition of senators including Malcolm Wallop, Republican of Wyoming, and Bill Bradley, Dernocrat of New Jersey. Since then, Mr. Bradley has been in the forefront of a group seeking diplomatic recognition of the Afghan rebels.

\section{$6 / 30$ - NYCT - The Afghan \\ Consul in Karachi has \\ disappeared. The Muslim \\ reported yesterday that \\ Baz Moh'd had fled with \\ "a wealth of information" \\ about DRA \& Soviet intel- \\ ligence activities in \\ Pakistan. He sold his}

household belongings last

week after receiving or-

ders to return to Kabul.

\section{RECENT DRA STAMPS}
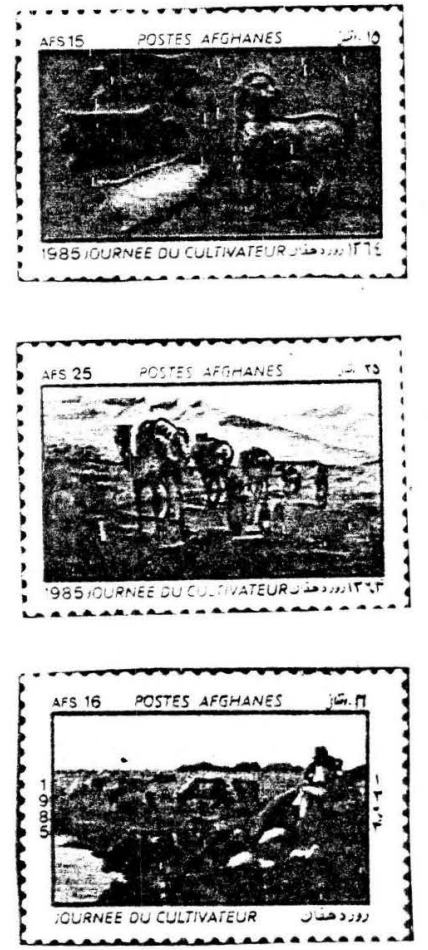


\section{Los Angeles. Times Service}

PESHAWAR, Pakistan - Rudyard Kipling de scribed this dusty frontier capital near the Khyber Pass as a "city of evil countenances."

Other cities lived. Peshawar lurked.

Kipling painted Peshawar as a place peopled by tribal warriors, smugglers, soldiers of fortune and spies. It was the playground for the great game of espionage between imperial Russia and its enemies.

Peshawar (pronounced pesh-AH-wur) has not changed much. It is still murky with intrigue and corruption.

Last month the provincial governor was forced to resign after his son was charged with running large shipments of heroin between Peshawar and New York. Among its many vices, Peshawar, population 700.000 , is one of the world's heroin canitais.

According to U.S. drug enforcement agents based here, as much as half of the American supply of heroin passes through this city in Pakistan's North-West Frontier province, only 35 miles ( 57 kilometers) from the Khyber Pass that leads from Afghanistan. The opium poppies are grown in Afghanistan and northern Pakistan. Big-time drug dealers have added the Mercedes-Benz to the traditional Peshawar street chaos of Land Rovers, camel carts and horse-drawn tongas.

Kipling's fearsome tribal warriors, Pathans and Afridis and Ghilzais, still strut through the streets. They are, for the most part, inarticulate men who express themselves by firing their rifles into the air.

Not long ago when a cocktail party was internupted by a burst from a Kalashnikov rifle, Sayid Ahmed Gailani, a retel leader, said, "Someone is celebrating a new baby or they are happy for some reason."

Mr. Gailani is an American-educated commander with the National Islamic Front of Afghanistan, one of more than a dozen rebel groups, or mujahidin. based here. The mujahidin use Peshawar as a base for carrying on their war against more than 100,000 Soviet troops in Afghanistan - and of ten against one another in the streets of Peshawar.

There are soldiers of fortune and adventurers here too, drawn irresistibly to the war - "the last fun war," in the words of an American television sound technician. a veteran of several forays into Afghanistan.

And spies. Except for Berlin, this might be the spy capital of the world. It is field headquarters for the largest covert Central Intelligence Agency operation since the Vietnam War. According to published reports, the CIA poured more than $\$ 400$ million into Pakistan last year to support the Afghan resistance.

The war has given military analysts their biggest opportunity since World War II to study Soviet weapons and tactics.

The analysts were delighted last year when deserting Afghan officers landed at an air base near here in the lacest-model Soviet MI-24 Hind helicopter.

They were not so pleased, however, when an American-supplied Afghan rebel base was blown up near Badaber, the site of the oid CIA air base from which Francis Gary Powers took off in 1960 in a U-2 spy plane that was shot down deep inside the Soviet Union.

The explosion was heard in Peshawar, 20 miles away, where such sounds are not unusual. There are bombings here about every other week, and Soviet secret agents and their colleagues in the Afghan secret police are usually blamed.

Still, many of the bombings are probably the work of one of the rebel groups. There is fierce competition among the groups for U.S. money and equipment, not all of which makes it into Afghanistan. The Saudi and Chinese governments also provide support to the rebels, reportedly about $\$ 200$ million worth a year. As in all wars, there are fortunes to be made here.

The rebel groups are also divided by tribal divisions.

\section{the Old Games Go On}

The 350,000 or so refugees who have lived in Peshawar since the Soviet intervention of Afghanistan in 1979 include royalists seeking the return of King Mohammed $\mathrm{Z}_{2}$ hir Shah, who is in exile in Rome; Maoists; Farsi-speaking Shiite Moslems; obscure Sufi sects, and dozens of tribes speaking dozens of languages and dialects.

Peshawar is a place, like Beirut, where it is unwise to sit near a window. When a bomb disrupted dinner last month at Lala's Grill, a popular restaurant at the front of Green's Hotel, the only people hurt were those sitting near windows.

A few days after the bombing, Lala's was patched up and waiters were hustling platters of mutton, a river fish called tikka, spiced quail and Russian salad. The place was crowded with its usual cast of characters: Afghans in turbans, French nurses, men in dark glasses studying maps, local politicians, even tourists.

Lala's is the gathering place for the flotsam of the war zone: reporters and would-be reporters, dope cealers and would-be dope dealers, rebel commanders and would-be rebel commanders. And there are those who are here to revel in the war.

"There are plenty of Walter Mitty types," Theodore C. Mataxis, a retired U.S. Army officer who is here promoting the rebel cause, said the other day, "and a lot of young men who drift in here and want to grab the elephant by the tail. They are on their way to Afghanistan to test themselves. They want to see how they will react under fire."

Among the regulars at Lala's, past and present, have been:

- Tanaka, a Japanese martial arts champion who recently went into Afghanistan to teach moujahedeen rebels how to kill Soviets with their bare hands. He was stricken with dysentery and had to come out before completing his mission. Still, there are several photographs scattered around $\mathrm{Pe}$ shawar that show him leaping high in the mountain air to demonstrate his lethal kick, with an Afghan rebel looking on uncomprehendingly.

- Lech Zontak, deceased, a Polish-Australian with a fierce hatred for Communists, particularly Polish Communists. According to Aaron Einfrank, a reporter for Radio Free Europe who knew him, "Lech had a dream of bombing the Polish Embassy in Kabul," the Afghan capital.
"He wanted to form an international brigade of East Europeans to fight against the Communists in Afghanistan," Einfrank said. "It was a good idea, but. Lech was the only member." Last fall, Zontak was killed in action.

- Ahmed and Kareem (not their real names), two American Black Muslims who sympathize with the rebel cause and came here to fight. Unfortunately, their fighting was not always limited to the battlefield. Christian Destremau, who is based in Peshawar with a French aid group, said he ran into Ahmed and Kareem in Afghanistan when he was visiting the big rebel base at Zhawar, in Paktia province.

"They accused me of being an infidel," he said, "and the next thing I knew I was on the ground and one of them was kicking me."

Destremau said he had not made the dangerous trip into Afghanistan to be beaten up by two Americans. He said the Afghan fighters, who have a high standard of hospitality, finally stopped the attack.

- Mataxis, an amiable, decorated veteran of World War II, Korea and Vietnam who retired from the U.S. Army in 1972 as a brigadier general. He is known affectionately in the Peshawar expatriate community as "General Ouzo," presumably because his name resembles a well-known brand of the Greek liqueur.

Mataxis, 69, bald and extremely fit, is the field representative here for the Committee For a Free Afghanistan, a Washington lobbying group that supports the rebels. Because of his extensive knowledge of weapons and guerrilla tactics, he is often consulted by rebel commanders. Before retiring from the Army, Mataxis served as a consultant to the Singapore Defense Ministry and as commandant of cadets at Valley Forge Military Academy in Pennsylvania.

"I feel very sorry for the Afghans and what has happened," he said. "I'm of the school that says the Russians are driving through (Afghanistan and Pakistan) to get to the warm water of the Arabian Sea. I thought rather than sitting around grousing at the club, watching the pine cones fail. I would try to do something to help."

Mataxis coordinates a program that provides humanitarian aid (seeds and medicine, for example) to rebel groups. He also arranges publicity visits to the United States for rebel leaders. 
"Politically, we don't have much trouble here," he said, recalling that this was not the case during his two tours in Vietnam. "This is a good war-mother and apple pie and all that-defending the poor Afghans against the Russians."

In fact, this once-remote outpost at the fringe of the British Empire is now a favorite stopping point for Western VIPs, particularly American congressmen. Ever since Zbigniew Brzezinski, national security adviser to President Jimmy Carter, came here and pointed a rifle toward Afghanistan, word has gotten around that this is a good show if you are on official business anywhere near Pakistan.

\section{Lots of Host Duties}

Vice President George Bush came in May, 1984. Officials at the U.S. Embassy in Islamabad say they are occasionally alerted that President Reagan is on the verge of visiting. Rep. Charles Wilson (DTex.), a strong supporter of covert funding for the Afghan rebels, arrived with a girlfriend, who slogged through the mud in white, high-heeled boots.

The American consul in Peshawar, Alan W. Eastham, finally had to ask for time off after hosting VIP delegations for nine straight weekends.

Visitors come to Peshawar by helicopter. An embassy officer who is familiar with the routine said, "Some don't even bother to go to the capital at Islamabad. They have it timed so they can do the whole tour in four hours."

The dignitaries arrive at a model Afghan refugee camp at the edge of Peshawar with magnificent hills serving as a backdrop. They are taken into a large tent for a meeting with the elders of the camp.

The ranking VIP makes a speech in English, though none of the elders speak any English, and often the translation is widely at variance with the speech as delivared. On one occasion, for example, "we support your fight against communism" was translated as "we support your holy battle against the infidels."

Afterward, the elders give the dignitaries rousing cheers and one of them rises to respond. Usually. this person throws in a request for more weapons, but this is not generally translated for the visitors.

When Vice President Bush was here, Gov. Fazle Haq of NorthWest Frontier province, a wily politician, insisted that the elder's remarks be prepared by the governor's office to ensure that it contained no request for guns.

The elder chosen to greet the visitor could not read, and he spent hours memorizing the speech as it was read to him. When he rose to recite it, many of his listeners smiled broadly, for he chanted it as though reading from the Koran. There was no request for weapons, though, and Fazle Haq nodded with pleasure.

After meeting with the elders, visitors are usually flown by helicopter to the regimental headquarters of the Khyber Rifles, where they watch tribal dancers and are served lunch on the regimental silver. Finally, they are taken to a place outside the town of Landr Kotl, where they can survey the world's most famous pass and imagine that they are Tamerlane or Genghis Khan or Alexander the Great, even though those historic invaders used a different pass, for the Khyber passage was not completed until the end of the 16th Century.

This is what is known as the "Peshawar Package Tour."

"We have a lot of drawing cards," a U.S. official based in Peshawar said-“drugs, the war, refugees, even the Pathan people themselves. That's why this town has more important visitors than most foreign capitals."

\section{SIGNS OF WAR EVIDENT IN KABUL}

Signs of the ongoing war between Soviet occupation troops and Afghan Wujahideen are increasingly evident on the streets of Kabul, according to the Baltimore Sun's Nioscow correspondent, Antero Pietila.

In a series of five articles between March 9 and March 13, he compares conditions in Afghanistan today with what he saw in 1984.

Pietila says the most striking evidence of increased Mujahideen activity around Kabul is the use of decoy flares day and night to deflect heat-seeking missiles fired on military aircraft landing and taking off from Kabul airports. He did not see any use of decoy flares back in 1984. He also notes that unlike two years ago, when he wandered about in Kabul quite freely, he could only move around now with a government escort.

Pietila says he was virtually under house arrest in a former 200-room intercontinental hotel that was heavily guarded and where he was one of two paying guests even though a staff of 159 people reported for work every day. Then, when he was allowed to fly to Mazar-i-Sharif, just 64 kilometers from the Soviet border, he was placed under even tighter surveillance; his government escort/interoreter was joined by $a$. Communist Jartv liaison afficial who stayed with him 24 hours a day.

Compared with 1984, Pietila saw more empty stores in Kabul and a slight increase in the number of signs in Russian. He also noted that food prices have skyrocketed over the past two years.

In the six years since the Soviet invasion, Afghanistan has become even more dependent on the Soviet Union. More than 70 per cent of Afghanistan's foreign trade is with Moscow, Pietila writes, and 45 per cent of the Afghan national budget is supported by natural gas exports to the Soviet Union.

In order to win the hearts and minds of the Urban middile class with cheap food and free education, the Soviet Union subsidizes the exports of such essentials as sugar, cooking oil, wheat and clothing. Even the transportation of goods imported from Europe and Japan is heavily subsidized as they pass through the Soviet Union to Afghanistan, Pietila notes. At least 10,000 Afghans go to the Soviet Union each year on scholarships with 1,500 attending deareeqranting institutions. : .

Pietila notes that the fervour of the holy war "Jehad" remains high, so much so that the Babrak Karmal regime is spending mill. ions of dollars to defuse the Mulahi. deen's Islamic power base. According to him, all Muslim clergymen

cont. on p. 19 


\section{Afghans' Second City Is Now \\ BY ARTHUR BONNER \\ Special to The New York Tímes \\ Mostly Ruins}

KANDAHAR, Afghanistan - Large areas of this city, once the second largest.,in Afghanistan, lie in ruins, and much of the surrounding countryside is devoid of normal life.

Rebel leaders in the region admit they are feeling the strain of a seemingly endless war of attrition. They say they have no medical supplies and no money to hire trucks to carry their seriously wounded to hospitals in Pakistan. They must sell captured Soviet rifles to buy food and blankets for their men or motorcycles for transport.

"Tell the world we are short of food," said Abdul Latif, the commander for about two dozen rebel bands in the Kandahar area linked with the National Islamic Front of Afghanistan.

"We are willing to fight, but our stomachs are empty," said Mr. Latif, a 75-year-old with a gray beard and soft, watery eyes, who arranged for a visitor to travel by night with a convoy of pickup trucks carrying arms and food to rebel areas. "With their planes and bombs they want to chase everyone out. If there are no people here to grow food, we will have to stop fighting."

Afghan journalists based in Peshawar and Quetta in Pakistan renort similar complaints from the Herat region in the northwest bordering Iran and from the strategic Panjshir Valley northwest of Kabul, the Afghan capital, ,

"We used to be rich," said Azizullah Mohammad, the wizened headman of the village of Kalach as he brought tea and bread for the only meal of the day. The convoy had stopped in the village for a night's rest.

"We had fields of wheat and potatoes and orchards of almonds, mulberries and apricots and gardens of grapes," he said. "We had sheep and goats and rugs for our floors, but now we have nothing."

He said only four families were left out of 10 that once lived in Kalach. He recited the names of a haif dozen nearby villages where all the families had left for the refugee camps of Pakistan, leaving behind shattered walls and crumbied beehive-style roofs like monuments to a dying civilization.

According to the rebels, Soviet troops are confined to an air base about six: miles southwest of the Kandahar, except for a few who are advisers to the Afghan Army or to civilian officials.

"I will show you that I control Kandahar," Mr. Latif said, organizing a cavalcade of motorcyles to take the visitor through the rubble-strewn streets.

Wide avenues were deserted, with store fronts only gaping holes. What were once modern schools or government buildings were twisted and cracked slabs of precast concrete.

Hulks of huge Soviet tanks lay buried in rubble. In one narrow street where there were some occupied houses, a tank blocked most of the way. But it was only a play object for children to clamber over.

Several of the larger bazaars were still active, with merchants selling food and canned goods. A shopkeeper said flour for making the large flat loaves $a^{-}$ bread that are the staple diet cost $\$ 1.85$ a pound, about a day's wage for a laborer. He.said the poor went hungry most of the time.

The rebels said Afghan soldiers or Communist Party members were seldom seen in most of the city. "If they show their faces, we will capture them," said one rebel, Fateh Khan.

Showing a mound of earth near his bașe, he said it was the grave of an Afghan Communist who had been captured in the city and sentenced to death by an Islamic court.

A mullah named Issa explained the death sentence.

"It is our belief," he said, "that is better to kill one Moslem who-fights against other Moslems in the service of the unbeliever than it is to kill 10 unbe. lievers like the Russians." NYT 6/1

\section{Afghan Rebels Face Tougher Foe}

\author{
By RONE TEMPEST
}

PESHAWAR, Pakistan-The Afghan rebels felt they had an impregnable position.

On one side of their mountaintop outpost in Afghanistan's Nangarhar Province was a sheer cliff dropping hundreds of feet to a river valley. The other side was a steep grade, passable but not without being seen from the commanding rebel position.

Yet shortly before dawn one day in March, the eight fighters with the National Islamic Front of Pakistan rebel group who were manning the post were surprised and killed by Soviet commandos, probably from the spetsnaz special forces.

Rebel commanders who examined the demolished post after the Soviets left came to a startling conclusion: The Soviet commandos had climbed the sheer cliff and attacked from behind.

"They must have," said National Islamic Front commander Mohammed Gailani. "There was no other way.", , I

The moujahedeen call them "the black soldiers" because the few that they have captured had darkened their faces for night operations.
"These are the best soldiers in the Soviet Union," said a highly respected rebel commander, Abdul Haq, 28. Haq commanded rebels in the territory around Kabul, the Afghan capital, even before the Soviet invasion in December, 1979.

Haq has seen the Soviet style of combat evolve from armies of conscripts and tanks, to large helicopter cavalry forces, to the quick-hitting special counterinsurgency units that favor night fighting.

"In Afghanistan," said the stocky young commander with disarmingly mirthful brown eyes, "you always have to make a quick decision. These spetsnaz are the only ones who can do that. They are older and they have better equipment. They don't operate like the other soldiers. They like quick attacks."

"It was much easier to capture conscripts," Haq said, "and much easier to take information from them. With these people (the special commandos), you need a special way to make them talk."

. The Soviet special forces have been given credit for several recent victories in the Afghanistan fight, ing, which revived in March with the annual spring offensive by Soviet and Afghan government forces. Last month, the rebels last one of their biggest bases, at Zhawar in Paktia Province, to a quick-hitting Soviet assault.

Although the rebels claimed to have inflicted serious losses on the Soviets-five jet aircraft and seven helicopters downed and more than 100 vehicles destroyed-it was a significant victory for the new aggressive Soviet style in Afghanistan.

Films taken of the fighting by the Hizb-e-Islami (Hekmatyar faction) rebel group were shown to reporters in Peshawar late last month. They showed hopelessly ill-equipped rebels on ridges above the Zhawar bases attempting to shoot down swooping jets and helicopters with rocket-propelled grenades designed for anti-tank warfare. ...

Like other rebel commanders, Abdul Haq is encouraged by reports in the Western press that the Reagan Administration has agreed to supply them with sophisticated Stinger ground-to-air missiles. ,

Meanwhile, not one of the rebel groups claims yet to have received a Stinger. In Washington, Pentagon officials would not comment on whether Stingers would be sent or have been shipped.
LA Times

$5 / 24$ 


\section{A REPORT FROM KUNDUZ ON CLOTH}

The news of a mujahideen attack written on 9 " $x$ 9 $\frac{1}{2}$ " piece of white cloth was carried from Kunduz via Kabul to Peshawar. It was then sent to Oregon where it was translated for the FORUM by Jamil Ranzoor:

4/15/86 Alcheen: A report from Cdr. Arbab Ghulam Haider states that the Jamiat-Islami mujahideen, headed by Cdr. Ghulam Naqshband launched a heavy attack on Russian \& Karmal forces entering Othmanzi village of Alcheen to search for anti-communists on $2 / 27 / 86$. Clashes took place from 6 to 9 a.m. As a result 9 Russian \& Karmal soldiers were killed \& several others wounded. Two Afghan mujahideen were wounded \& 3 captured. Russian \& Karmal forces were unable to take their dead bodies. Later the 3 Afghan mujahideen were exchanged for the dead bodies. The 3 mujahideen, Saifurrahman, Ghulam Yahya \& Moh'd Nadir, returned to their group. The mujahideen also seized 13 kalishnakov machine guns \& some ammunition in these clashes.

\section{NEW BOMBS}

\section{From Afighan liews 5/15:}

According to a report sent by Cdr. Ahmad Shah Masoud of the Panjshir Valley the Soviets have been heavily bombing the valley since the beginning of May. As well as the ordinary bombs they used before, they are using 2 new types:

1) Time-delay bombs which explode several hours after they have been dropped. They are timed to explode in the morning, noon, evening \& night. 2 ) An unknown bomb about 1 meter long \& 1 meter in diameter, These are dropped from MiG-29 \& SU-25 jets. The bomb is a brick red color with shiny light tail fins. These bombs weigh most at the tail \& this end penetrates $\frac{1}{2}$ to 1 meter into the ground. The surprising thing about these bombs is that none of them have yet exploded. The bomb does not appear to be heavy. When they are dropped, a flare is also released from the plane...
WHO IS NAJIBULLAH - from the AICMB 非62, May:

Najibullah was born in 1948 in Milan village... in Paktia Province into a relatively wealthy family of the Ahmadzai tribe. His father, Akhtar Moh'd served in the Royal civil administration in Kabul \& was for a time the representative of Afghan traders \& also the Afghan Pashtani Commercial Bank in Peshawar where Najib went to primary school. Najib graduated from Habibia College in 1965. He was admitted to the medical college of Kabul $U$ \& obtained an $M D$ degree in 1976... Najib has 3 brothers \& 2 sisters (the eldest being married to Nek Moh'd, a former member of parliament from Shomali, \& the younger to a man called Sangar, a hard line Parchami). His wife Fatana belongs to a Kabul aristocratic family of Mohammadzai (the royal clan). Najib is very fond of a comfortable life, drinking parties \& pretty women.

He became a member of the Khalq Democratic Party in 1966, 2 year after its creation. When the party split into 2 rival factions he joined the Parcham group led by Babrak Karma1. In 1972-73 he served as spokesman \& leader of the Parchami students at the university... In 1977 he was ap pointed by the CC of the Party as a member of the 3-man liaison committee with the Soviet Union... In February Iy7y...the Khalq \& Parcham Factions came together \& Najib was appointed a member of the joint committee... other Parchamis were Babrak, Noor Ahmad Noor \& Mir Akbar Khaybar... Najib became a full member of the CC in February, 2 months prior to the coup, in which neither Najib nor other Parchami leaders were directly involved. When the Parchamis were expelled... Najib became ambassador in Tehran. A few months later they were again dismissed \& Najib fled to Prague with the embassy's funds. [See Afghanistan Council Newsletter, Vol. VII, 非, p. 10] Five days after the Soviet invasion (12/27/79) Najib came to Afghanistan in a Soviet air convoy, landed at Bagram airbase \& was taken directly to the Gov't Palace in Kabul. He was appointed head of KHAD...\& given the rank of brig. gen'1. He became a full member of the Politburo in 1982... Najib made out of KHAD the only efficient organ in the whole communist state structure. Five main directorates with various depts. in the army \& civil administration were created in each province... In 1985 he was appointed as $\sec ^{\prime} y$ of the CC \& on 4/4/86 he became gen'1 $\sec ^{\prime} y$ of the Party $\&$ chmn. of the CC. (See also p. 35.) 
Excerpts from "Afghanistan: The Bleeding Wound" by Sergei Khovanski in DETENTE, Spring 1986

The Soviet intervention in Afghanistan has revealed that Soviet troops are insufficiently trained and badly organised. Reserve cadre divisions, or, as they have been nicknamed by the military, "castrated" divisions, were very difficult to make into combat-ready military units. And it so happened that initially to conquer Afghanistan the Soviet military leadership had mobilised precisely these reserve divisions of the Central Asian military district. At the end of 1979 only six divisions were stationed there; these were only at $70 \%$ of their numerical strength. As a result, at least two divisions within the contingent that was sent to Afghanistan were third-rate, so-called "castrated" divisions. They included mostly inhabitants of the Central Asian Republics and very few Russians. They were urgently 'beefed up' with local reservists, most of whom had spent their military service in construction battalions handling a pickaxe or a spade, or working at the railways. When they were demobilised they were automatically placed on a register of the local divisions, to which they were subsequentiy sent on the eve of the Afghani operations.

In the initial period after the Soviet invasion the resistance movement suffered because it remained within the framework of a typical peasant war, with all the shortcomings inherent in it. The partisans had not yet fought away from their native villages and therefore it was extremely difficult for them to manouevre. to exploit the successes achieved in one area of the front in order to develop an offensive in other areas.

In 1984 from among the partisan commanders a leader emerged who provided an example of military organisation and social enterprise for the whole of the resistance movement: his name is Pandjsher Massoud. During the years under his leadership the rebels managed to repulse seven massive Soviet offensives, where dozens of heavy bombers, hundreds of combat helicopters tanks and APC's, and thousands of soldiers took part. His military victories roused the political leaders of the resistance movement to call on their followers within Afghanistan to rally round Massoud, and these were the leaders who had previously spent most of their time while in Pakistan intriguing against each other. As a result of these changes, towards the end of 1984 the greater part of Afghan territory came either under full partisan control $(60 \%)$ or was under double control (30\%).

The analysis of the development and the results of the Afghan war shows that siy years after it began, the Soviet army is further away from victory than on the first day of the intervention. And as the perspec- tives for a military solution in Afghanistan fade away, the need for a political settlement of the conflict becomes increasingly urgent. It is inevitable that the military failures in Afghanistan would strengthen the position of those politicians within the Soviet leadership who tend to think realistically. This has become even more probable because the war in Afghanistan was the result of obviously mistaken actions of the previous, Brezhnev leadership.

The new Kremlin leadership, headed by Gorbachev, can truly consider itself without guilt in the Afghan crisis, and this has created favourable conditions for the commencement of a process of reconciliation talks with the Afghans. Moscow is forced to sit down at the conference table not only because of the military defeats, but also because of the heavy burden that this war has placed upon the Soviet economy. In addition, as the number of human losses in the Soviet army increases (according to the most modest calculations they came to 10,000 dead and 25,000 wounded during the past six years) dissatisfaction grows proportionally within those strata of Soviet society from which the soldiers are called up. It is interesting that among those nations which inhabit the periphery of the USSR this dissatisfaction more and more frequently takes the form of open resistance. Acts of protest are quickly and ruthlessly suppressed and for that reason information about them rarely becomes known to world public opinion. Nevertheless the demonstration of protest staged in Erevan in 1985 became widely known.

In June of the same year in Astrakhan, recruits called up for army service, mainly Chechens from the Northern Caucasus, who arrived in this city, clashed with military authorities when the latter told them that they would be trained for Afghanistan. The Chechen youthis categorically refused to go to Afghanistan, explaining that they did not wish to kill their Moslem coreligionists. In the course of a fierce clash, whose outcome was decided by the troops, there were wounded and kilied on both sides, although not of course in equal numbers. This was probably the first act of anti-war protest in the USSR suppressed with firearms.

- Pravda has published material without a precedent: an unsigned article (which emphasises the official status) entitled "For the Broadening of the Social Basis of the Afghan Revolution". It begins as follows: 'To commence a wideranging dialogue ..." Then follows an admission which is surprising for the Soviet press: "By no means all the people in Afghanistan, even within the working strata, have accepted the April Revolution. the policies promoted by popular power..."; "the mistakes of the first stage of the revolution: getting carried away by revolutionary phrases, introducing social reforms by force without due consideration of the reality of the situation, the social and national characteristic features of the country ...": and finally the most important: "In order to eliminate the prejudices that have accumulated, to disperse the illusions, time is needed. It is necessary to create a climate conducive to a positive dialogue between social and political forces, including those who for the time being adhere to a.stance hostile to the revolution for the sake of the national rebirth of Afghanistan".

This article-constitutes perhaps the urst serious indication that in the Soviet ruling circles a shift towards a solution of the Afghanistan problem is emerging, from the military approach towards a political one. At the same time the reactionary and clearly chauvinistic wing of the Soviet leadership is very active. This group is linked with former leaders of the country and with influential people within the military. One of their spokesmen, the writer A. Prokhanov, in an article published in Literaturnaya Gazeta ${ }^{3}$, very clearly presented the views of this group: war is better than peace. During times of peace when everything is well organised, we become demoralised. The army is stagnating in the garrisons and loses the habit of real fighting. A war would invigorate us, it would tighten up discipline in the army, it would rejuvenate the nation. Already the author is happy that young people who earlier used to listen non-stop to Vysotsky's songs, now, looking much more severe, listen silently to 'ballads' about Soviet soldiers beating off an attack of the 'dushmans' (bandits), about how our Kaiashnikovs roared. However, Prokhanov mentioned neither socialism nor internationalism, nor even social progress. He mentioned revolution only once in connection with Afghan exotica. We, he announces, are defending in Afghanistan our cause as a world power (!) and we are fighting for the "balance of global space", for "space equilibrium"! i.e., in other words, for the same notorious lebensraum. Without any doubt Prokhanov is a worthy successor to Purishkevich - the leader of the Black Hundreds'.

It is clear that a one-sided withdrawal of Soviet troops from Aighanistan would not bring an end to the bloodshed there, and it would not bring an end to the Civil War. Therefore if the USSR indeed strives to end this war, and at the same time to acquire a stable and friendly state on its southern border, it ought to begin direct talks with the Mudjahaddin. Of course to do that it is first of all necessary to acknowledge them as a warring side and to relinquish attempts to show the partisans as bandits (dushmans) and counter-revolutionaries (basmachi). At this point it is worthwile reminding ourselves that the tsarist goverenment in the

2 Pravda, 21.12.1985, p.4.

${ }^{3}$ Lit. gaz., 28.8.1985, p.14. 
XIXth century treated its military opponents in Central Asia and in the Caucasus with great respect. To be more concrete on this point, direct talks ought to be conducted with the political leadership of the Afghan resistance, or at any rate with the Gilani and Rabbani groups capable of forming the future coalition govemment of the independent and neutral Afghanistan. The sooner this process starts, the smaller will be the influence of third countries (the West, Iran or Pakistan) on the future government of the republic. Independently of political talks with the opposition parties, an internal agreement on a cease-fire with Massoud and other leaders like him in various localities is very much needed.A precedent for this is the short-term agreement Massoud concluded with Soviet troops in 1984.

Troop withdrawal would have to be gradual. A certain number of soldiers from the occupying army could remain in the country during the transition period. During the talks it is necessary to try to secure guarantees for Soviet borders and invioiability for those people who co-operated with the Soviet administration and with that of Karmal, but are not otherwise guilty of any crime. The withdrawal of Soviet troops could be accompanied by free elections. Rhodesia could serve as a mode! of political regulation for Afghanistan, where the troops from both sides finally became integrated into one army. In any case Afghanistan will badly need Soviet economic aid and Soviet specialists; this would give the Soviet Union certain advantages at the talks and would give grounds for hope for an honourabie peace.

\section{For an anti-war coalition}

However, the condition for such a sucessful outcome would be a timely and radical change of policy on the part of the Soviet Union, and first and foremost a readiness to achieve a compromise. In the present situation the anti-war movement is capable of playing if not the decisive then at least a very important role, in contributing to the isolation of the 'Prokahnovites' in Soviet society on the one hand, and in strengthening the positions of the realists among the ruling circles, on the other. The anti-war demonstrations which took place in 1985 in themselves constitute an important political factor. They bear evidence to the shifts that are taking place in the mood of the masses, at least in the periphery of the country. A new social activeness has emerged in place of the old apathy and depoliticisation. And finally the last point: the quest for a way out of the dead end in Afghanistan draws together the moderate reformers, who are active in the upper echelons of the system, and the progressives and the left movements, whose positions are more radical. These movements are only just now begining to take shape, and their future depends on the overall dynamics of the political situation in our country, on the tempo and the extent of the changes promised by Gorbachev's group.

In this respect one hopes that the following phrase from the Prauda article quoted earlier becomes a guideline to action: "Naturally it is not easy to overcome differences of opinion. Reconciliation presumes certain compromises". "If this were to come true, then without fail peace would reign again in the long-suffering land of Afghanis$\tan$.

4 Pravda, 21.12.1985

\section{Afghanistan: propaganda war}

While the Kremlin appears to be giving signs for a phased withdrawal from Afghanistan the Karmal regime in Kabul is busy convincing the Soviet allies and the west that the war against the Mujahideen has almost been won. Journalists with socialist credentials from the west as well as the third world, including many Muslim countries, are being invited to visit war torn Afghanistan to measure themselves the extent of the Mujahideen's influence.

Last month 37 journalists and officials from the west and the third world countries were present in Kabul as state guests. They were taken around Kabul and surrounding villages to talk to Afghans in the presence of the Russian troops and the Karmal regime officials. The purpose of these government conducted tours was to show that the Karmal regime was in full control of the situation and the Mujahideen were losing ground in almost all areas of the country.

A careful analysis of the stories filed by these journalists in their respective papers and magazines suggests that almost all of them were exposed to people planted in the villages before the visit by the regime. These include people the journalists quoted as ex-Mujahideen who never participated in the Jihad inside Afghanistan, as is confirmed by the Mujahideen groups.

In addition, information given to the visiting journalists by the regime contradicted the earlier communique issued by the Karmal regime. According to reports appearing in the British Guardian newspaper and Channel Four television, as well as in some Pakistani and Arab world newspapers and magazines, the Mujahideen are no longer able to prevent the Russians and their Afghan allies from controlling most of the major population centres and pushing the security perimeter of each city gradually outwards into the villages beyond.

This contradicts the official statement given at the beginning of this year by the Afghan defence ministry. In its January resumé of the ongoing . war in Afghanistan, the government said that during 1985,512 battles took place in which 5,843 Mujahideen were killed. The actual number of face to face battles according to Mujahideen sources was 2,548 , in which 7,936 Karmal and Soviet soldiers were killed, and 4,554 were captured. In this statement the government also admitted that despite announcing big incentives to Afghan refugees, not many have returned to Afghanistan. The government also deplored the fact that "many young Afghans are becoming involved in counter revolutionary activities", The Karmal regime also admitted its failure to win over "the villages who are still the main supply line of the Mujahideen".

Some of the newspapers, particularly the Guardian which represents socialist trends in Britain, have referred to Ismatullah Khan who, according to them, recently defected to the Kabul regime, after fighting with the Mujahideen for nearly four years. Ismatullah Khan was never with the Mujahideen and was killed last year when a fight broke out between two pro-regime warring groups over some personal issue.

The journalists have also reported that many mullahs were now participating in government. This negates the government's earlier statements describing "mullahs as retrogressive and obscurantists who have always sided with the feudal lords.

The journalists and officials who have visited Kabul as the regime's guests have questioned the relevance of the continuous world support to the Mujahideen. They have argued that the Mujahideen are basically reactionary and Islamic fundamentalist and if they come to power the west and liberal countries may have to fight another battle against fundamentalism. They have suggested that the Karmal regime should be accepted now as during the last six years of war it has won over the masses and initiated policies aimed at restoring human rights and freedom and justice. They also have warned third world and western governments against being trapped by the Mujahideen propaganda that they are winning the Jihad. . .

The recent propaganda campaign through the media does not however take into account that already four million Afghans are living as refugees in Pakistan and Iran with almost 20,000 more joining them every month. The propaganda also fails to take notice of the contradictory statements issued by the Karmal regime. Afghan watchers think that the new wave of propaganda is primarily aimed at finding out a face saving device for the Soviet troops who, when asked to withdraw, would question, "What did we gain in Afghanistan". The Soviet authorities would then claim, that they had 'institutionalised justice and freedom', however far this may be from the truth. 


\section{Afghan Students Look to Karmal}

\section{as Anti-Soviet Symbol}

Babrak Karmal, regarded by many as the perfect Soviet stooge during his six years as Afghan communist party chief and president, appears to have suddeniy become a symbol of resistance - at least in the eyes of Kabul students.

Mr. Karmal went to Moscow at the end of March, apparently for medical treatment. When he failed to return after one month during which the official media made a point of dropping the usual praise for his revolutionary achievements, students at Kabul University began to protest against his absence on 30 April.

On 1 May Mr. Karmal was back in Kabul but demonstrations in his support picked up the following day when the Central Committee of his communist People's Democratic Party of Afghanistan, PDPA, opened a meeting that was widely expected to bring leadership changes. Soviet troops with tanks and helicopters were deployed in a show of force to deter any attack on the building where the conference took place, while Afghan army troops were kept away from the area. The unusually drastic measure was seen by many in Kabul as clear evidence that the expected reshuffles were being imposed from above by Soviet power - ironically, in the same way that Mr. Karmal himself had been installed in December 1979

On 4 May came the announcement that Mr. Karmal had 'resigned' from his post as party general secretary for health reasons and that the PDPA leadership had 'decided' to replace him with former secret police chief Najibullah.

At least six further protest demonstrations were reported in Kabul until 6 May, when police beat up and hauled away two busloads of girl students from the French-language Malalai lycée. The girls had chanted, "Death to Najibullah. We want Karmal. Out with the Soviets. We want an Islamic government." Mr. Karmal has always cultivated his public appearance as a devout Muslim, even though his party works to achieve strictly communist goals over the long term in direct contradiction of Islam.

Secret police used violence to break up three other protests by mostly high school students, including two involving girls.



Babrak Karmal

In an apparent effort to avoid further trouble, Mr. Karmal began appearing at official functions during the following week in the company of Mr. Najibullah and Prime Minister Sultan Ali Keshtmand. Kabul-based diplomats said he really seemed to be in bad health.

On 15 May, Mr. Najibullah announced that a new collective leadership had been formed, including him, Mr. Karmal and Mr. Keshtmand.

He explained that Mr. Karmai, as chairman of the Revolutionary Council and its presidium, would be concerned with strengthening the "state power organs," apparently referring to the armed forces which are notoriously plagued by desertions. He stressed that Mr. Karmal had resigned from the all-important party post for health reasons and praised what he called his "great role" in the so-called Saur revolution of 27 April 1978 - the communist coup

Mr. Najibullah said Mr. Keshtmand would deal with the ministries, administration and the implementation of economic policies, while he himself would devote his attention to the task of strengthening the PDPA.

He claimed that the party now has 155.000 members, of whom 64 percent or nearly 100.000 "have arms in hand and are defending the country." while, that Mr. Najibullah wanted to make his home province of Paktia an example, following his pledge on taking power that he would "inten-
It appeared last week, mean- sify the struggle" against the Islamic resistance. After nine days of heavy bombing of villages and guerrilla strongholds in the strategic Jaji area of Paktia, on the Pakistani border about 80 kilometres southeast of Kabul, Soviet and Afghan forces launched a vast ground offensive on 14 May. The attack, within a few days after the start of Ramadan, was the first since Mr. Najibullah became PDPA chief.

One of the easiest and most important mujaheddin supply routes runs from the village of Teri Mangal in Pakistan's Kurram Salient up the mountains along the border to Jaji and beyond into the interior of Afghanistan. The route represents the shortest distance between the border and Kabul.

Hamid Sherdil, an Afghan doctor who arrived in Peshawar from Jaii on 15 May, estimated that some 500 tanks, armoured personnel carriers and trucks had arrived in the area on the day before he left. He reportedly said the communist forces began their big drive during the night, dropping flares and setting "the mountaintops on fire with incendiary bombs so they could see where they were.... It was as bright as day."

He said that as he left Jaji before dawn, fighter jets spewing dozens of decoy flares bombed the area, while ground forces pounded it with mortars and BM-13 'Stalin Organ' multiple rocket launchers.

The offensive came as the Afghan and Pakistani foreign ministers continued their seventh round of indirect talks in Geneva on a settlement of the conflict. U.N. special envoy Diego Cordovez, who mediates in the discussions, said when the latest round began on 5 May that they would likely take at least two weeks. The most important issue being tackled by the two sides now is a timetable for a withdrawal of the more than 100,000 Soviet troops from Afghanistan.

Dr. Sherdil said he found the normally bustling village of Teri Mangal empty when he passed through the area and Pakistani border guards had abandoned their post in the mountains beyond after it was half destroyed in shelling by communist forces. Teri Mangal has been bombed and shelled many times during the past few years and. as recently as 13 May, communist artillery fire killed 14 Afghan refugees there.

ITAFF REPOIRT 


\section{Afghanistan Fights for Its Soul.}

\section{Islamic Self-Determination, Not Soviet Army, Is the Issue}

\section{By M. NAZIF SHAHRANI}

Babrak Karmal has stepped down-or has been pushed out-as head of the Marxist government of Afghanistan, and the seventh round of preliminary talks to end Afghanistan's war are under way in Geneva. A "breakthrough" is now hinted, but eight years after the Soviet-inspired coup, Moscow's agenda remains the same: recognition of the regime in Kabul, no matter who is in the role of chief puppet.

In an effort to resolve the conflict peacefully, U.N. Undersecretary General Diego Cordovez has made numerous trips between Moscow, Kabul, Islamabad and Tehran in the past four years. These trips, and the six rounds of U.N.- mediated "proximity talks" in Geneva, have now come down to Soviet willingness to offer a timetable for withdrawal of troops from Afghanistan. But first there would have to be nonintervention agreements between Afghanistan and Pakistan, which would require Pakistan to recognize the government in Kabul, and the end of outside support to the Afghan moujahedeen. If this is all that the U.N. special envoy could negotiate after years of effort, the chances are dim in the near future for a peaceful end to the tragic war in Afghanistan.

Most basically, the current proposal does not address the real issue of the war, which is the Afghan people's desire to establish an Islamic and truly nonaligned government, as expressed by the Islamic Unity coalition of the seven major Afghan resistance groups operating in and out the country. It is critical to point out that the war against the Soviet-imposed communist regime began more than a year before the Soviet invasion of December, 1979, and will continue long after the Soviet troops are withdrawn if the Afghan Communists remain in power.

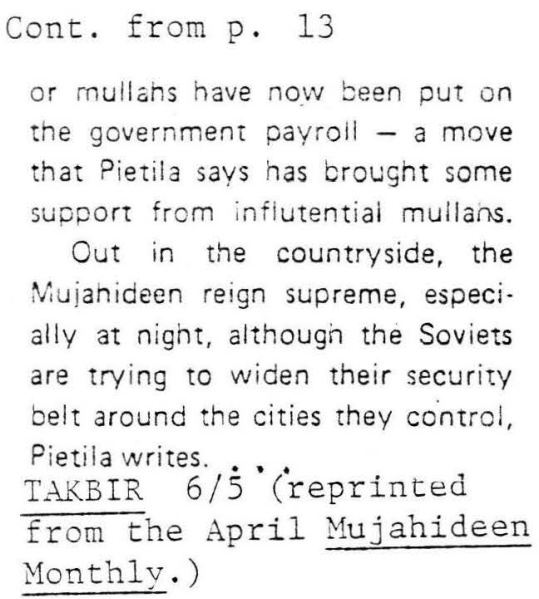

If agreed upon, the proposal now on the table in Geneva would only legitimize the Soviets' claim that the principal parties in the conflict are not the Soviets and the moujahedeen, but the regime in Kabul and the so-called outside forces of Pakistan, Iran, China and the United States. If this absurd Soviet claim were confirmed through a U.N. agreement, the Soviets would have a new and more potent "legal fiction" to use for any future invasion and occupation of Afghanistan, if and when they find the survival of their puppet regime in Kabul threatened.

In Geneva, the Soviets also are making the supposedly charitable proposal for repatriation of more than 4 million Afghan refugees living in Pakistan and Iran. This assumption that refugees would flock home when Soviet troops are withdrawn ignores the fact that there were more than 1 million Afghan refuges in Pakistan before the Soviet invasion of 1979 , as a result of an continuing armed rebellion against the previous Moscow-allied regime in Kabul. The removal of Afghan refugees from Pakistan may be in the interest of the Pakistan government, but how will that government "repatriate" unwilling refugees back to a regime that forced them to seek refuge in Pakistan in the first place?

Finally, it would be a mistake to believe, as the Soviets allege, that the resistance will collapse if U.S. and Pakistani aid is withdrawn. The moujahedeen resistance is not comparable with the contra movement in Nicaragua. The Islamic-inspired armed struggle, or jihad, in Afghanistan is a truly popular resistance movement. It began and intensified very rapidly inside the country without any meaningful outside help. It could continue for a long time without any substantial aid from the outside, especially now that most Afghans living in the rural areas have become armed over the past seven years of war.

In its present form, therefore, the U.N.engineered proposal only attempts to address some major symptoms of the conflict; it ignores the causes. As such it may provide a first step toward reaching a peaceful solution, but it cannot be regarded as a comprehensive formula for ending the war in the foreseeable future. That will require a recognition of the rights of the people of Afghanistan to determine their own political future.

The Afghanistan conflict is too complex to be solved through real or imagined proxies. No solution will ever be possible without taking into consideration the wishes of Afghans. They have been struggling for eight years, not only to rid their country of the Snviet Red Army and its puppets in Kabul, but also to establish an Islamic government. Until the Islamic Unity of Afghanistan Moujahedeen is part of the process, the world should take any "breakthrough" at Geneva as only the most preliminary of preliminaries.

\section{May 7 Ias Angeles Otimes}

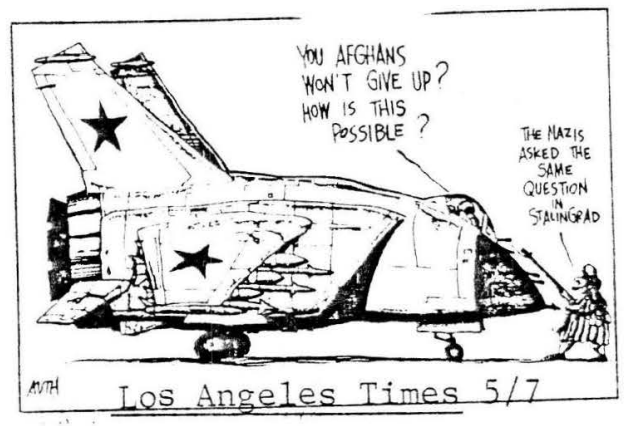

DOST SHE OR DOST SHE NOT?

A DEATH IN CANNES. Shahnawaz Bhutto, brother of the Pakistan opposition leader Benazir Bhutto, was found poisoned last July in an apartment in Cannes, France. Was he murdered, or did he commit suicide? If he was murdered, was the motive political or criminal?

Shahnawaz Bhutto, like Benazir Bhutto, had been in exile since their father, Zulfikar Ali Bhutto, was overthrown in July 1977. He was executed by the Government of Gen. Mohammad Zia ul-Haq in April 1979. But unlike Miss Bhutto, Shahnawaz Bhutto did not engage in overt political activity. Earlier this year, Miss Bhutto returned to Pakistan from her home in London, apparently prepared to act as a focal point for opponents of Gen- eral Zia, the country's military leader and President.

Meanwhile, complete mystery surrounds the death of her brother.

The French police have charged Shahnawaz Bhutto's wife, Rehana, with failing to give help to a person in danger, asserting that she did not do enough to save her husband when he became ill from the poison. But she has not been accused of murder. The charge against her has not yet come to trial and she continues to live in the Cannes apartment.

According to Elizabeth Granier Zarrabi, a French lawyer retained by the Bhutto family, the French police continue to "experiment with the poison" used to kill Mr. Bhutto. But she has said that nothing is known about the results of these investigations and she describes the affair as "cloaked in uncertainty still." NYT' $6 / 2$ 
The media has covered the Soviet occupation of Afghanistan extensively, but as Merryle Wyn Davies argues the images they have conveyed are at variance with reality.

IN December of 1979 Russian tanks and troops rolled into Afghanistan. The operation was conducted in full view of the western media. The pictures were sent around the world and did much to stimulate and confirm the outcry and protests which greeted the Russian invasion. It seems the Russians had expected to be welcomed by the populace. They claimed to have moved in at the request of the Afghan regime to help 'save the revolution'. Under the leadership of Hafizullah Amin the year old revolution had been brutal and stirred up strong resistance. The new Russian appointed leader, Babrak Karmal, was to saivage the path to sovietization and secure the 'reforms' of the revolution. Pernaps that is why the international press corps was allowed to remain in Kabul

The pictures of tanks and troop carriers at street corners looked just like those engrained images in the western media's memory of Hungary in 1956 and Czechoslovakia in 1968. Very soon there was no longer an international press corps in Kabul.

Throughout 1980 Afghanistan continued as a big story in the western media. But, as in so much of the reportage, Afghanistan and what was happening to its people was a brooding absence in the coverage. What made Afghanistan a 'big story' was the threat, and imposition of an Olympic boycott. The Moscow Olympics presented the western media with a neat issue. They had trumpeted the cause of liberty and freedom for Afghanistan and called for strong action in response to the Soviet invasion. When the politicians offered the notion of not playing games with the Russians this raised its own questions about the freedom and liberty of a western audience to be entertained as it had expected.

I well remember doing an interview with former Olympic gold medalist Chris Brasher at the height of the controversy. He commented that the whole furore showed the impotence of politicians, content to use 16 and 17 year olds as propaganda fodder in default of having any realistic policy. But Afghanistan was a high profile story in 1980.

The mainstay of reporting which has kept the war in the newspapers are the battle notices. These notices vary from the occasional one paragraph to a full column accompanied by a map.
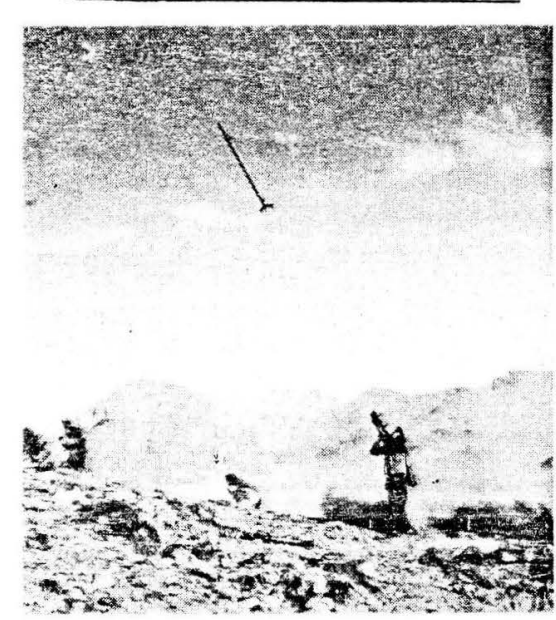

The glorified media image of a high-tech Afghan mujahid

The essence of the story is an engagement between Soviet and Afghan troops and the Mujahideen. In such stories names of places and commanders and details of troop deployments are scattered around with great authority. What they can convey to their readership is another matter.

If one follows these occasional reports one finds they come in bursts. Each new appearance claims to report a vital engagement which will significantly affect the course of the conflict. Details of weapons and tactics are listed, as are likely targets and objectives. The initial story will be followed by small mentions which can last for days, even weeks. Then, somehow, the story just fades away. The keen follower of the press would be at a loss to know whether this is because the engagement has ended, though then one might expect a result to be announced, or whether the paper has just lost interest in a battle which is continuing to no great denouement.

This is what makes the neatness of the battle reports from Afghanistan so interesting. Given that there is no resident press corps travelling with the combatants, how can the synopses be so precise? There are only two available sources for the western media First the western diplomats based in Kabul, many of whom are specialists in military intelligence, and secondly the Mujahideen. The Russians have not made a practise of giving military briefings on their activities.

The diplomats are settled in Kabul. We get persistent-stories about the Mujahideen being able to strike at the heart of Kabul. of explosions and gunfire in the night. On such occasions the diplomatic corp are direct sources.
But their assessments of activities beyond the purview of the captial is obviously just that, a paper assessment from available, though undisclosed sources of information. The reports of the Mujahideen are fed to the western media through Pakistan, which has become something of a Afghan watching station. By virtue of being fed through Pakistan the reports must either precede or come well after the fact of the action.

There is nothing sinister or disturbing in the sources of information, they are the only way in which any news of Afghanisatn can be obtained. The importance of recognising the sources of news is the shape it is bound to impose, the effect it has on the understanding of the war amongst the audience of the western media. Related at a distance the details of conflict become strategic, matters of neat lines, it becomes a clean conflict removed from the consequences of fighting, such as blood and gore, human suffering. Even the sense of daring, fear and heroism can have no place in sanitised accounts made up from a variety of sources, a definite portion of which, have no direct experience of the nature of this war.

This mainstay of reporting which keeps Afghanistan in the western consciousness consists of detail without context. In effect it is little more than a statement that Afghanistan is still there, and still at war. It can convey nothing of the quality of the country and the conflict, and most certainly conveys little of the human cost of the war upon the population of Afghanistan.

Information without a context does not just float rootless in people's minds. The detail provided will be fitted to whatever images or preconceived ideas come readily to hand. The saga of the media coverage of Afghanistan in the last six years has been the triumph of the stereotype over any attempt to grasp reality.

From the time of the Communist coup of April 1978 when the government of Mohammad Daoud was overthrown Afghanistan has never emerged from its time warp. The resistance to the Kabul regime and the Russian invasion has drawn most forcibly on ideas and images of the Great Game. The Great Game was how the British incursions into Afghanistan in the last century came to be known. The objective then was to keep the Russian bear at bay. Now the Russian bear is getting the sort of treatment which greeted the British. It is always the British or the Russian who are the focus of the story, because they are the known and knowable entity. The Afghans are the sturdy warriors, the freedom loving fighters, independent, 
fierce, bedecked in turbans and bandoliers who are the shadowy figures harrying their opponents.

Afridis and Gilzais, names of tribal groupings, are terms redolent of the Great Victorian Adventure stories. There is a sense of incredulity, can they still be doing the same thing, by the same means? Yes. The tactics, at first even the weaponry, and the hostility, we are assured, have not changed much over the years. The warrior race is doing what warrior races do: fighting tooth and nail.

This kind of information is refreshed in the public's mind in feature articles. Clearly journalists have done their homework and read the history books. But then the history books on Afghanistan have been written by the British. So the images which are conjured make the Afghan fighter a formidable character but one remote from western understanding. The feature articles make Afghanistan a present issue which is remote in distance, social context and even remote in time from the western audience. It is ever the case that distance softens the enormity of tragedy and suffering which is being endured.

In the coverage of Afghanistan what must be noticed is the way in which inherited stereotypes have reinforced certain journalistic conventions to slant the reporting of what is happening. Given that the mental picture of Afghanistan is formed from nineteenth century myths it has also been added to by the hippie treks of the 1960 's and '70's. So the backwardness that called for the taking up of the white man's burden has been compounded by the image of an untouched, undeveloped bandit country. Here tribalism holds its sway as from time immemorial and all is confusion in which the natives can be given but scant reliance.

The Mujahideen are organised in at least seven distinct organisations each

of which, allegedly, will make ex. aggerated claims for their military en deavours. The proud fighter, with overtones of the bandit who is definitely strange and totally non-western becomes a questionable source of information. It is interesting to note that the organisations of the Mujahideen are not asked about policy and programmes, in the same way as other resistance movements are reported. The conflict conducted by the Mujahideen has endured for six years against all the sophisticated weaponry of a superpower. Yet the aim and purpose of the fighting is seldom subjected to conventional scrutiny.
The conventions of the press have much to do with this. The experience of the journalist is always taken to be paramount. His function in any situation is to check facts. Facts can only be said to be properly checked when both sides of an issue have been reviewed. Afghanistan is a war in which neither side appears to have been questioned because neither side falls into the category of reliable source, for the western media. The Russians are well known to indulge in double speak and not to disclose information. The Afghan fighters have the legacy of their stereotyped) personality and history counted against them. In such a situation, when there is certainly a story to be covered, it is the journalist himself who steps to centre stage.

Nowhere can this phenomenon be more clearly seen than in television. This medium ought to have enabled something of the quality of the war to be reported. In fact Afghanistan is probably the clearest indication there ever could be that the camera lens can only record the story in the jouralist's mind. In the journalists mind, Jevoid of the usual sources and mechanisms upon which he relies to gather and disseminate information all he can reflect through the camera lens is himself and his subjective response.

Most television coverage of Afghanistan has come from freelance reporters and crews who have been prepared to undertake the rigours and risks of entering Afghanistan along with Mujahideen. The undertaking has itself become a convention. The pictures they bring back dwell at great length upon the hardship of the trek through barren and rugged countryside. The war footage shows a few desultory discharges of weapons by the guerillas and sound effects off camera constitute the war. Then there is the wobbly picture of a Soviet plane or helicopter passing overhead. Quite otten there is no footage to show what effect the engagement had. Small shapes and dust clouds in the distance are what the weaponry has done. Rubbled masses of stone are shown as evidence of air raids but they are rubble which accumulated some time ago. The anguish and the bloodshed caused by helicopter gunships and bombing raids have yet to be seen, as have the injuries they inflict.

We have even been treated to coverage by night sensing cameras, infra red pictures of warfare by night. They appear to contain exactly the same elements as pictures taken by dav. In unlocatable, often unidentifiable, confusion these pictures are the war as it has been shown on the western media. These pictures, which can give no sense whatsoever of the reality, are unquestionable because the western journalist was there. They are the only solid information which exists.

This is the news genre of coverage. In news, events alone have importance. To show Mujahideen walking here and walking there, cowering behind rocks and firing off shots, this is news. It is an event, something is happening. The story however is the process by which the news was got. The clearest example of this are the documentaries of Sandy Gall, an eminent British newscaster who went off to Afghanistan. It includes all the stock pictures, crossing rivers, walking over mountains and all the while he is heard relating the hardship he suffered. At one point he and his crew even contemplate buying a piece of meat, the one and only piece in a village shop, even though it was host to hornets, who suddenly come into dramatic closeup. If he can make such comments, he was not hungry, but it all adds to the atmosphere of journalist as hero.

Sandy Gall's report is the fullest expression of the news coverage of the Afghan war. His mission is to go and get back in one piece. His objective is an interview with Masood, the leader of the fighters in the Panshir valley. We actually see little of Masood, hear less of what Masood has to say for himself. But we hear a great deal of Sandy Gall talking about Masood. Indeed while this is a television documentary it relies a great deal upon words. The explanation is simple. So much of what is relevant information cannot be brought before the cameras unless the journalist is willing to devote the time to wait for the action of the war. What can happen can only be filmed by those willing to remain in places where bombing raids are in progress and then show the cost. On a quick visit they have to mock un demonstrations of tactics and techniques.

The second fascination, having watched Mr Gall's report is to review and realise for the first time that it was contemporaneous with another documentary from Afghanistan. This programme was made by a French film crew travelling with a group of French doctors who provide medical relief inside Afghanistan. The French doctors do three month tours of duty. In that time they become familiar with the pattern of the war, and the people who endure the war and fight the war. All this is reflected in the quality of the pictures that can be put on the screen 
I had seen both programmes before. But until I watched them one after the other for the purposes of this article I had not realised that they contained almost exactly the same footage, though taken at different seasons of the year. Masood was a central character in both programmes, though one got a different sense of Mr Gall's description of him by hearing him converse in French in the other film. In French he did talk about more ordinary matters, like picking up a clot of phosphorous from the remnants of a Russian bomb and burning his fingers. Both films visited the same gaol where prisoners are held. For Mr Gall this was a major news point. For the French a much more informal encounter with another aspect of the war.

It was not just the factor of time which made exactly the same pictures tell different stories in both these films. It was the difference in the importance of risk which made the programmes different in their striking similarities. For Mr Gall risk was the story, each picture was grabbed breathlessly and exhibited as a major trophy. So the picture had no thought to context, to telling a story, to conveying the quality of a conflict and the lives of the people engaged in it. The picture was the story. For the French the risks were there, the doctors were female, French, and heroic but the risks did not predominate. Therefore the pictures were able to give a sense of place and of living which was identifiable. One could sense that life was going on under duress, there was a community which existed. The clear give away was the essential footage of prayers. For Mr Gall this had been organised specially and formally for the benefit of the camera. The French caught daily prayers as they happen, daily, with the familiar informality which accompanies normal events. Yet neither programme showed us the casualties of the war.

The logistics of covering the war in Afghanistan, however, cannot be the only explanation for the equivocal tone of so much that is written. Supposedly this a fight for freedom which has the clear and certain backing of the western powers. But the fighters are not only a peopie who are world away from the life style of the west. As time has gone on the Afghan issue has taken on the overtones of western coverage of Islam, as the passion which stirs and motivates the conflict has become evident to western journalists.

The fierce independent fighters ready to take on a superpower and not relent takes on quite a different perspective when that same fighter is another potential recruit for 'fundamentalist Islam.' Afghanistan is after all the neighbour of Iran, whose image in the west does not need to be repeated. The Islamic dimension is clearly a problem for many. In the last year as the Mujahideen organisations have become more coordinated, as they have become more clearly identified in the media's mind with the label fundamentalist and as perhaps something of their aspiration for Afghanistan has sunk into media consciousness the tone of coverage has perceptibly shifted.

It can be no accident that more and more stories are now written about the potential destabilising problems of the Afghan refugees in Pakistan. The mechanics of international refugee relief have created the conditions in which the Afghan refugees have had greater opportunities for systematic education of their young people. They need no education in the conflict which has uprooted and blighted their lives. But they now have access to education, both religious and technical, which will make them a very different proposition from their forebears. Islam as 'fundamentalism' is a force which the west sees with uncomprehending hostility because it believes it means only uncompromising hostility towards the west. Pakistan has the kind of Islamisation which the west can live with, after all General $\mathrm{Zia}$ is still a very dependent ally of the United States.

Indeed the spectre of Islamic fundamentalism amongst the Afghans has been taken even further by Alain Chevalerias, who obviously views events through the viewpoint of the French Medecine Sans Frontieres who have sent their doctors to work inside Afghanistan. Chevalerias now sees an Islamic conspiracy to convert the Afghans to the worst anti-western 'hardline Muslim fundamentalism.' Indeed his neurosis goes so far as to speculate that winning the hearts and minds of the Afghans to the Iranian cause is now more important than combating the Russians.

It is one further twist of the chaotic fragmentation and in fighting view of events which has been a familiar part of coverage of Afghanistan since the Russian invasion. Yet it is a shift of emphasis which merely confirms so much of the stereotypes upon which the coverage has relied. The people of Afghanistan have become no more familiar, no more understood in all the efforts that have been made to present them in the western media. The exercise of reporting seems to have been one of strengthening the stereotypes and confirming the thoughts one began with.
Ever since Mr Gorbachev came to office he has been making noises about a possible Soviet withdrawal from Afghanistan. Concern for the propaganda image is known to be a high priority with the new Soviet leadership. Afghanistan too has been having its image soothed by the Soviets for the benefit of the western media. For the first time in many years western reporters have been allowed to view the country from the Soviet side. Needless to say they have found short comings in the reports of the corps of diplomats upon whom they have relied.

Suddenly journalists are able to visit villages outside Kabul. They can witness the policies of the Afghan regime in action: They can talk to villagers. Once more the journalists are back on firm and solid territory, doing their job as they understand it. Their conclusion is that war weariness is bringing people over to the government. A subtle policy of local autonomy is being followed which makes this a less painful process than it might have been. The Kabul regime is even allowing the mosques to operate, buying the sevices of the mosque functionaries and religious leaders.

It would seem that in the last year the Afghan situation, while being no more widely reported than in previous years, has however crossed a threshold in which it can be subjected to more routine media scrutiny. The diversity of the stories which have resulted being a testimony to the hard work of the journalists. That may be what we are supposed to think, but it is far from being what has happened.

Whatever side the conflict is viewed from one can only notice the invisibility which still attaches to the Afghan war. One can only see the questions of journalists as being dedicated to the maintenance of the gaps in awareness which keeps the fate of the Afghan people absent from western thinking and feeling.

Unless facts and statistics are kept in a context they can lie glibly. The population of Afghanistan was 15 to 17 million. One third of that population are now refugees, and new refugees are still arriving in Pakistan and Iran. The estimates of the death toll are put at one million. Afghanistan was a poor agrarian economy before the Russian invasion, there have been six years of war in which villages and farms have been devastated, often as part of a conscious scorched earth policy. Such land as is cultivated is worked by a fraction of the population which once grew crops. For planting and harvesting this may not be an insurmountable problem but much of Afghan agriculture depends 
upon irrigation, how is this maintained and kept in working order when so much of the population has had to flee the land?

While reporters may reflect the new policies of the Afghan regime and see them as profiting from war weariness inside the country, what of the' views of one third of the nation's people who still do not consent to these policies? Can valid conclusions be drawn from a visit to Afghanistan which does not mention the will of the remainder of the Afghan people?

Afghanistan has been an invisible war in which fragments and glimpses have been taken as sufficient to get an overview, a complete picture of events. Yet the human cost of the war has never been part of the equation. The napalm and phosphorous bombs, the reports of chemical weapons, the bombs disguised as toys and innocent objects have been heard of- but the human wreckage has not been seen. It needds the compassion inspired by endurance of such suffering to get some clearer vision of the depth of loyalty to the ideal of independence which has sustained the Afghan resistance...

When people become real participants in their own tragedy then the price of realpolitik becomes too high to pay.

Afghanistan has not reached that point yet. It is still unfamiliar and hostile territory in which the media takes the easy option and makes up a storyline for a war it cannot see. In failing to capture the human cost of this war the media confirms the interests of realpolitik and the calculation which finds Afghanistan a useful bargaining counter between East and West, and even in keeping Islam at



The reality behind the images
STARS FOR AFGHANISTAN by Benjamin Stein,

$\frac{\text { WSJ }}{6 / 18}$

Could this be magic?

On a recent night at the Mark Taper Forum of the Los Angeles Music Center, a gathering of stars of big and small screen turned out to hear speeches about Soviet atrocities in Afghanistan-Soviet atrocities, committed by Russians against women and children in the Panjshir Valley and in Pol-i-Charki Prison.

Dennis Prager, a local rabbi and radio talk show host, told the audience that the Russians had killed one million Afghans, and that this was a real genocide, ". . . and not just any genocide, but a Soviet genocide. The murders were not done by just anyone. The Russians killed these people." Richard "Down and Out in Beverly Hills" Dreyfuss and Cliff "AT\&T" Robertson cheered and applauded.

Dr. Robert Simon, a physician who has frequently treated young children with fingers blown off by Soviet booby traps, talked about how he wants to make amovie about the killings in Afghanistan, only it will not be like "The Killing Fields," ". . . where you leave the theater wondering who was at fault. In the real story of Afghanistan, only one group is doing the killing--Soviet Russia." Terri "Mr. Mom" Garr and Linda. "The Exorcist" Blair and Conrad "Diff'rent Strokes" Bain applauded vigorously.

An Afghan refugee wearing full Pushtu headdress, Mohammed Tahir, stood up and took bows from agents and business managers. He wore a patch over the eye he had lost fighting a Soviet tank. Tom Newman, who wrote the score for "Gung Ho" and "Desperately Seeking Susan," applauded until his eyes became moist from emotion. Another Afghan refugee, Hassan Nouri, stood in the orchestra pit, his black eyes blazing, and explained that the Russians were killing 22 Afghans per hour, every hour of the day. He ended by saying, in a stirring voice, "God Bless America, the hope of mankind." The whole crowd, which had been supported and joined by donations from Ed "Lou Grant" Asner and Jerry and David "Airplane" Zucker and Olivia "Gone With the Wind" De Havilland and Paul "Diana" Anka and Suzanne "Three's Company" Somers, stood and applauded.

Is this a dream? Can it really be that in Hollywood, where the slightest criticism of the Soviets is generally taboo, and any criticism of the American way of life is usually treated as revealed truth, a medley of stars came and paid money and lent their very large talents to a night of salvation for the Afghan people and sharp criticism of the Soviet Union for its savaging of Afghanistan?

It can be, and it is.

Janice Prager, a large part of whose family died at the hands of the Nazis, got the idea for the evening from a simple thought: "If we Jews really mean it when we say 'never again' about genocide, we have to really stand up about any genocide, and say never again to the Soviets in Afghanistan."
Ms. Prager and her husband, Dennis, organized the evening of speeches and a performance of Stravinsky's musical drama "The Soldier's Tale" to raise money for a clinic built into a cave in Afghanistan to treat the wounded. They enlisted three major stars, Messrs. Dreyfuss and Robertson and Ms. Garr, to lure other stars and to perform the Stravinsky work.

"It was not at all hard for me to get involved," Mr. Dreyfuss told me. "I'm against genocide. I'm against totalitarianism. We here in Hollywood have a tendency to divide issues into left and right. This isn't that kind of issue. Criticism of the Soviets for what they have done in Afghanistan should be across the board."

Is this a watershed in Hollywood? Could we possibly see a giant rock telethon for Mujahideen-Aid? According to Mr. Dreyfuss, it could very well happen if the news media get out the word. "People in Hollywood are not sensitized to things unless the media make, us be aware. So far, the media have not done anything like the job on the Afghans that they did on Ethiopia."

(As if to underscore Mr. Dreyfuss's point, at a well-advertised press conference before the performance there were only three reporters, and none from the powerful Los Angeles Times, or from any local TV station except KCBS, or from any local radio station except $\mathrm{KNX}$.

Frankly, the evening went on too long. It could not even be saved by the fine readings from the three star-organizers, who showed for the first time in my sight that they were actors, and not just stars.

But the real point had nothing to do with Stravinsky or a few long-winded speeches. The point was that the influential, powerful Hollywood community can be reached by a humanitarian appeal that unequivocally points the finger at Soviet brutality. Happily, the Hollywood monolith can visualize and feel for the Afghans who have been burned alive or thrown down wells or napalmed in hospitals or machinegunned in front of graves they have dug themselves, even if the killers are from a group usually immune from criticism anywhere near Sunset Boulevard. The stars present at the fundraiser for the Afghan Jewish hospital were not the "old guard" of Reagan pals such as Bob Hope or Efrem Zimbalist or Robert Stack. Monday's glitter was from men and women who would normally run with the prevailing "progressive" tide in Hollywood.

Clearly, it takes very determined and devoted people like the Pragers and Richard Dreyfuss to bring it off. But Hollywood can be made aware of a duty to use its star power to save the innocent from Bolshevik cruelty, and not just from evil bankers or giant chemical companies or from the CIA. If Hollywood, especially younger Hollywood, can see the truth, it can show the truth to a vastly larger public, especially a vastly larger younger public.

Monday night at the Mark Taper was a night of hope not just for the mujahideen, but for Tinseltown, and for the country it serves. Even stars can see the light. 


\section{The Afghan War: a Ray of Hope}

Two events brack-



eted the latest round of U.S.-sponsored talks in Geneva aimed tuward withdrawal of the 115,000 Soviet soldiers occupying Afghanistan.

Before the talks began, the Soviet Union replaced its puppet leader in Afghanistan, Babrak Karmal, with a different puppet, Najibullah. The day the talks closed, Pakjstan shot down a Soviet plane, which had violated Pakistani air space to attack the Afghan freedom fighters.

This was not the first such violation by the Soviets, but the first such reprisal by the Pakistani air force. Pakistan President Mohammad Zia ul-Haq hould now be stronger against the critics who claim that the arms he receives from the United States, presumably to combat the Soviets in Afghanistan, are used only against the Pakistani people. Now those arms have been used, at least once, as they were intended.

The personnel switch, Najibullah for Karmal, was window dressing by the Soviets aimed at increasing their credibility with the most powerful element in Afghan society, the Pathan tribes.

But few Pathans were fooled. Some Western analysts said that because Najibullah heads the Afghan secret service and is close to the Soviet KGB, his appointment indicated a hardening of the Soviet position. Afghan leaders smile at that. No one could be closer to the KGB than Karmal, whom they suspect of being a longtime KGB agent.

Karmal is Mr. Afghan Communist. He was a charter member of the undercover left-wing movement that eventually succeeded in 1978 with a Marxist coup. He was the Soviets' best friend in that first Marxist government, even suggesting that Afghanistan become a Soviet Socialist Republic. Fellow revolutionaries, not quite so Soviet-obsessed, exiled him. He went with his friends, including Najibullah, into Eastern Europe where Afghans believe that he promoted the Soviet invasion. The Soviets, newly respectful of pubiic relations, shed a symboi that had become a ijabiiity, as they entered new negotiations.

Najibullah belongs to the Ahmedzai tribe in the federa tion of Ghilzai, under the general grouping of Pathan.

It is the Pathans whom the Soviets wish to cultivate. Tribal identity is a factor in Afthan politics that cannot be overestimated. The ethnic maneuvering that we see in the United States is mild by comparison. In 1929 an uncle of Najibullah aspired to rule Afghanistan, although he was a nomad horse trader. The Ghilzais had been ousted from rule in 1725 and did not regain power until 1978 when one of their own, Nur Mohammed Taraki, headed the first Marxist government. Don't think the passage of centuries has diminished the significance of all this or mollified the emotions. It hasn't.

Pathans live on both sides of the frontier between Afghanistan and Pakistan and have never seen why the frontier should matter to them.

The Soviets entered the negotiations with a plan to extend their troop withdrawal over 12 months during which period $\mathrm{Pa}$ kistan would close the frontier. Never in history has any power succeeded in closing that frontier. The Soviets, according to Afghan reasoning, know that Pakistan would fail. That would give them the right of pursuit; they would say to Pakistan, "Let us come in and help you." And another country would come under Soviet rule.

The interplay between afghanistan and Pakistan is absorbing, we forget that Iran is on the other side of Afginistan. Many tribes close to Iran are Shiite, as are the Iranians.

The bad news is that the Iranian Communist Party, the Tudeh, is reported active in that region as well as in Kabul. The good news comes in a letter from Matt Erulkar, an American who just spent four months inside Afghanistan in the central and northern regions, even crossing the Amur Darya River into the Soviet Union, unlike most travelers who simply get their toes wet along Afghanistan's eastern frontier.

"Iranian influence has increased dramatically in areas west and northwest of Kabul," he wrote. "However, confrontation between the Shiites and Sunnis has decreased largely because Shiite groups, more assured of their dominance in these areas, are focusing on Soviet targets rather than on Sunni convoys passing through. Shiites and Sunnis are cooperating and sharing strategies."

By becoming the common enemy, the Soviets have created what centuries could not: unity among Afghan groups. The factions of freedom fighters, notorious a few years ago for their disunity, have joined forces. All were represented in Geneva - not officially at the conference, but outside, talking and poiiticixing.

They said they would ignore any solution that did not please them, meaning one that did not permit Afghans to choose their own way of life.

They would continue fighting.

The conference is over and the fighting continues. But the Soviets see a need to court the tribes with the time-honored chauvinism. The West is more assertive. It adds up to a slight tilt westward. 


\section{Exiles Fight for Cultural Survival}

\begin{abstract}
SUMMARY: A "talking tree" and the voice of a 3-year-old girl are a couple of the signs of Afghan resistance to the Soviet occupation. They are part of an operation being conducted by a group of exiles to provide books and other materiais to fight illiteracy and to counter the destruction of the country's culture and educational system.
\end{abstract}

I $\mathrm{n}$ the Afghan capital of Kabul, Najibullah, the new leader of the Sovietbacked government. promises to wage an even bloodier war against the anticommunist resistance. But in the rebel-held countryside, another war is being fought with books and tape recorders - against illiteracy, against the destruction of the country's culture and educational system by the Soviet occupation.

Its voice is that of a 3-year-old girl sending her tape-recorded blessings to the mujahideen, the Muslim "holy warriors" of the resistance who - vastly outgunned by superior Soviet weaponry - are fighting the invaders to a standstill. "Greetings to you." she says. "Go and fight the infidel Russians. When I grow up. I will have a gun and kill the Russians myself. God be with you."

Its voice is also that of a talking tree. in a storybook written for the children of the war. The tree speaks of the importance of preserving trees in a countryside being devastated by the Soviets' scorched-earth policy. "My most vicious enemy today is the Russians," the tree says.

Since the Soviets invaded Afghanistan in 1979 to prop up a faltering communist government that took power in a coup a year earlier, they have waged one of the most brutal wars in Afghan history, creating some 5 million refugees, according to the U.S. State Department's annual human rights report. "The Soviets' central and long-term objective appears to be to absorb Afghanistan into the socialist system by reshaping that country's traditional Islamic society into the Soviet mold as they did in central Asia in the 1920s." the report said.

"The Russians are teaching the children to hate the mujahideen," Sabahuddin Kushkaki, head of the Afghan resistance's literacy campaign, said at a recent Washington news conference. Because of that, he explained, a group of educated Afghan exiles has launched a counterattack, intent on building an educational infrastructure for a new Afghanistan after the mujahideen victory they are convinced will come.

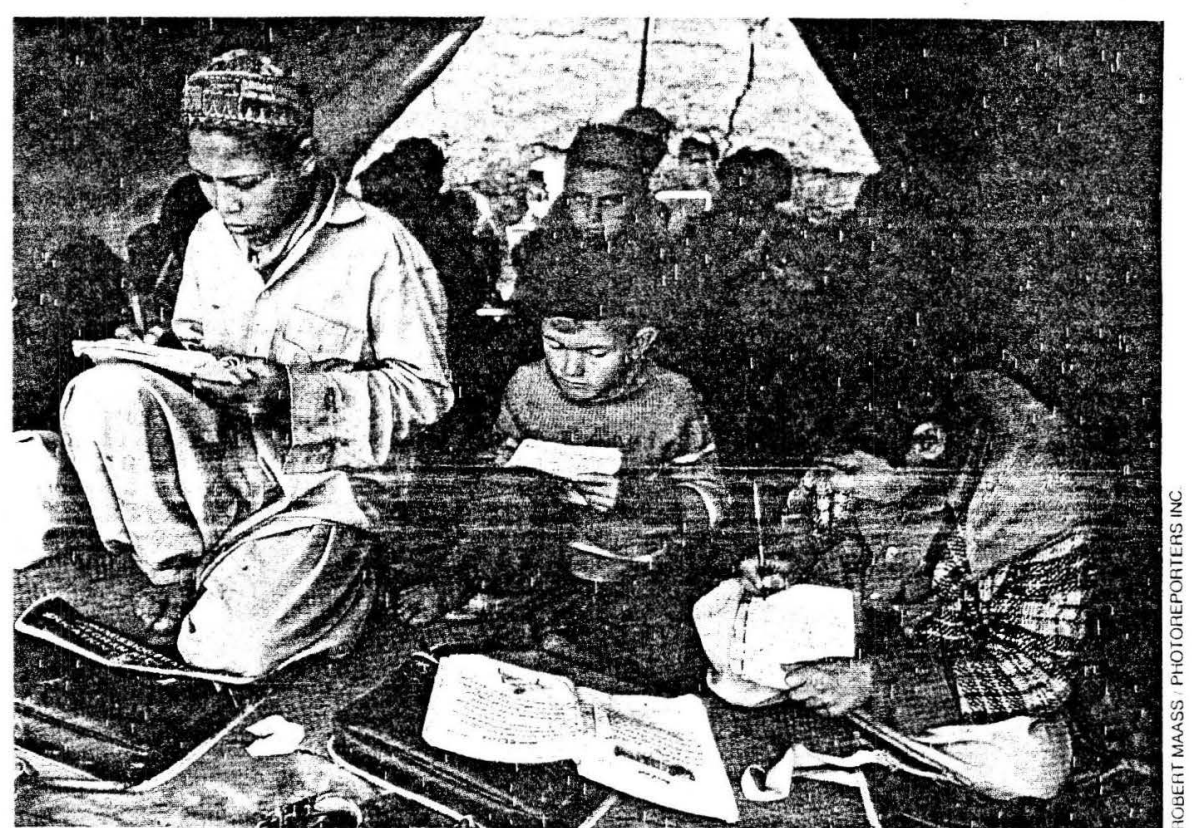

Afghan children attend school in Pakistan. Many back home aren't so lucky.

Afghanistan has often been the target of foreign invaders, from Alexander the Great to Genghis Khan, from the British to the Soviets. "They feel if they can sustain this war for seven years, they can sustain it for as long as there is one Afghan left to fight." Kushkaki said of the rebels. "History has taught them they cannot be defeated.

We feel the people who are running the war will be the people who will run the country. We want to teach them to read and write and teach them about the war." Kushkaki said.

Armed with a $\$ 180,800$ grant last year from the U.S. National Endowment for Democracy and with the help of educators at the University of Nebraska's Center for Afghanistan Studies. Kushkaki and his colleagues have so far distributed 75.000 books, trained teachers and opened 10 schools in guerrilla territory. "They are not buildings where bells ring and children come to school," he said. "Classes could be in a mosque, under a tree or in someone's house.

Operating from headquarters in Islamabad, Pakistan, they wrote or rewrote 60 textbooks. some of which were in use before the communist takeover. The books are smuggled into Afghanistan by the rebels along the same routes they use to bring arms and supplies to their camps. "The subjects in many of the old textbooks were no longer relevant. You cannot isolate yourself from your environment," Kushkaki said. "They will not accept books that do not teach the children how to survive."

The messages from the little girl on the tape recorder and the talking tree in the storybook are part of a larger campaign, he said. It is designed to reflect the realities of war and preserve an Afghan culture threatened by the Soviets' policy of Russification - the systematic destruction of the Afghans' ancient ways and the indoctrination of Afghan children in Soviet schools.

The government closed all but 50 of the 1,900 village schools operating before the communist coup and is sending many children to the Soviet Union for instruction. About 1 million children in Afghanistan are without any schooling, according to Kushkaki. Along with opening their own elementary schools and training teachers. Kushkaki's Cultural Council of Afghanistan Resistance is distributing cassette tapes to counter Soviet propaganda, which runs 18 hours a day on the radio and five hours a day on television.

The center has also acquired six video cameras and trained Afghans to operate them. The group wants to record the war for the outside world and to create a documentation center. "Its significance cannot be overstated." Kushkaki said. "Most of the published materials in Afghanistan, whether it be textbooks, historical documents, religious books, museum articles or other materials representing Afghan society, culture, values and tradition have been systematically destroyed."

- James Morrison 


\section{Urban Refugees in Peshawar}

The repair yard just off the old grand trunk road that runs from Kabul and the Khyber Pass, across Pakistan and down through India, is a sea of mud from a recent winter rain. But the ceaseless hammering and clanking amid the parked trucks, dismantled engines and piles of scrap suggest that it's business as usual. Scores of workshop shanties line the yard where some two thousand Afghan refugees - mechanics, welders, painters and apprentices - repair vehicles owned by fellow countrymen now living in Pakistani exile...

Ever since the first Afghan refugees began fleeing to neighbouring Pakistan in mid-1978. Peshawar has rapidly developed into a mini-Kabul. The city's population has nearly doubled to 1.2 million, at least a quarter if not a third or whom are Afghans. Although most of the estimated 2 million refugees who have crossed over into Pakistan's. North-West Frontier Province are of Pushtun, or Pathan, origin, growing numbers of Afghans such as Tadjiks or Uzbeks from other parts of the country have lent Peshawar a distinct Central Asian flavour.

Not only has Dari (Afghan Persian) begun to flow as freely as Pashto in the bazaars, but the clothes, the facial features and the customs representing Afghanistan's varied ethnic background point to a gradual transformation in this city's traditional Pathan character. Kabul merchants have transferred their import-export operations to the back alleys of Peshawar, Turkomen from Mazar-iSharif hawk carpets in the streets, Tadjiks from the Panjshair drive buses in university town and Pathans from Khost work on construction sites in the new industrial districts.

Many of the Afghans found during the day in Peshawar are actually registered refugees living in the surrounding camps. They come in from the outlying settlements to work, shop in the bazaars or seek medical care among the dozens of clinics and support groups established by international relief organizations since the early 80 s.
To avoid tension, the Pakistani authorities also seek to keep Afghan political activities away from Peshawar itself. Resistance party headquarters have been restricted to the suburbs and single young men are not allowed to spend the night in town. Police regularly check the hotels and other local premises to ensure that they return to refugee villages in the outlying areas of the Peshawar district.

Nevertheless, Peshawar commands a sizeable population of urban refugees who are not registered with the villages but live according to their own means. Often several families together, they tend to reside in houses or apartments in and around the city.

Some urban refugees, despite losing their homes inside Afghanistan, have done very well. Their businesses ranging from car dealerships to transport services and video shops are flourishing. Many a refugee has rented or bought a fine suburban house not only in Peshawar but also Islamabad, Karachi and other Pakistani cities. Over the past five or six years, Peshawar has turned into a boom town. Much of this is a result of funds brought in by the refugees and international aid programmes. Drug smuggling, too, however, has contributed to the town's new wealth. Although Pakistani tribal groups are primarily involved, so are certain Afghan refugees provoking considerable concern among the authorities.

Nevertheless, for numerous Afghans of urban background, the going is tough. Not living in camps, they do not benefit from financial assistance. "As it is", noted one west European relief official, "there are enough Pakistanis who resent Afghans in the camps, living rent free and receiving rations, and who work in the towns. If we were to start helping urban refugees with regular relief this might cause further friction."

Academicians, for example, particularly those from the universities, are unable to find comparable jobs in Pakistan. The end result is that most eventually emigrate to third countries, notably the United States and western Europe. "We should really be staying here to help our people by teaching. It is vital to pre: vent our culture from dying", noted Professor Say- ed Mohammed Yusuf Elmi, formerly of Kabul University. "But there are no jobs, so how can I support my family? I will have no choice but to leave for Europe or America." Of the estimated 300-odd college professors and lecturers who have fled to Pakistan, most are believed to have now sought 'asylum elsewhere....

Although the possibilities for further education are severely limited, efforts are being made to promote self-reliance through vocational training schemes. Several of the International Relief Agencies have established long-term courses for Afghan medical personnel in Peshawar clinics. Other groups are providing English language and teaching programmes.

One reasonably successful scheme, a multi-purpose mechanical training centre, is run by the Austrian Relief Committee in Peshawar's university town. A six-month course enables young Afghans to learn metal work, auto repair and electronics. But it also runs courses in English, mathematics and other subjects. "The idea", explained mechanical engineer Fazul Haq Faqiri, "is to train them enough so that we can send them out to professional workshops as apprentices until they are good enough to get full-time jobs."

During a visit to the centre, some of the 90 Afghan trainee participants were taking apart engines, and then putting them together again, with instructors advising them over their shoulders. Others sat in classes learning mechanical theory, but also English, mathematics and history.

Some now work in the bazaars, while others are being sent out to the refugee camps where the coordinators have begun to establish subcentres. Similarly the Austrian Relief Committee has a programme whereby it provides small amounts of financial assistance to help mechanics set up their own operations such as the purchase of tools. "They may be refugees now, but we've got to think of the time ahead when they can return home. They will at least have a trained profession", said Austrian Relief Director Nassim Jawad. "One's time in exile should not be wasted. Life must continue." EDWARD GIRARDET

REFUGEES - March 1986 
THE ARIZONA REPUBLIC

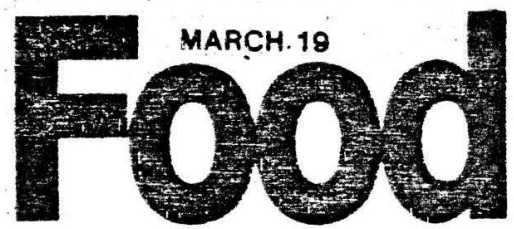

From an article by Judy Hille; recipes by Cathy Parenti.

\section{'Buranee bonjawn'}

(Eggplant stew)

1 large eggplant, sliced diagonally

$1 / 8$ inch thick

8 ounces plain yogurt

2 cloves garlic, minced

Salt and pepper to taste

Vegetable oil for frying

1 large onion, sliced $1 / 4$ inch thick

1 large sweet green pepper, julienned

2 large tomatoes, sliced $1 / 4$ inch thick

1 teaspoon ground dried spearmint

: Score the eggplant slices and salt each slice. Allow the slices to sit for one hour. Wash off each slice and dry with a paper towel.

In a bowl, thoroughly blend the yogurt, garlic, salt and pepper, set aside. Do not refrigerate.

In a frying pan, heat the vegetable oil and fry each eggplant slice until soft and golden. Drain on paper towels. When you have fried all the eggplant slices, transfer them to a platter and keep warm in a 200- to 250-degree oven. Fry the onion and pepper and garnish the eggplant dish. Fry the tomatoes and add to the dish. Pour yogurt sauce over the eggplant platter and sprinkle with ground mint. This is eaten with East Indian chapatis, or whole wheat pita bread.

Makes 4 servings.

\section{'Kishtah chalow' \\ (Dried apricot rice)}

9 ounces long-grain brown rice

$1 / 4$ pound (1 stick) of unsalted butter

1 large onion, chopped coarsely

3 chicken breasts, cut up in chunks

6 ounces dried unsulphured apricots, soaked overnight

4 tablespoons golden sultanaraisins

2 tablespoons ground cinnamon

Salt and pepper to taste

22 ounces boiling water

$1 / 2$ teaspoon salt

3 tablespoons vegetable oil

3 ounces water
Soak the rice in a bowl of water for 3 hours.

In a saucepan, melt the butter and saute the onion until golden. Add the chicken chunks and brown gently. Then add the apricots, sultanas, cinnamon, salt and pepper to taste and saute 10 minutes covered. Put the apricot juice into the pot with enough water to cover the chicken and bring to a boil. Cover, stir and simmer until the chicken is very tender and the sauce thick, about 45 minutes.

While the chicken is cooking, wash the rice and drain. In a pot with a tight-fitting lid, bring 22 ounces of water to a rolling boil with $1 / 2$ teaspoon of salt. Add the rice, cover and cook vigorously over medium heat until all the water is absorbed. Rice should be tender but not thoroughly cooked. Add 3 tablespoons of vegetable oil and 3 ounces water to the rice, mix well and cover and steam on the lowest possible heat for 20 to 30 minutes. The chalow will be fluffy and each grain separate. Use forks to mix and serve. Put the chicken in its apricot sauce in the middle of the rice and serve.

Makes 3 servings.

' Kormay rowash' (Rhubarb stew)

1 large onion, chopped coarsely

- 2 ounces vegetable oil

1 pound lean boneless stew beef

Salt and pepper to taste

1 tablespoon ground allspice

1 pound rhubarb stalks, washed and cut into 2-inch pieces

Juice of $1 / 2$ a sour orange or lemon

In a saucepan, saute the onion in 1 ounce of vegetable oil until golden. Add the stew beef and brown. Add salt, pepper, allspice and enough water to cover the meat; cover and bring to a boil. Lower heat to simmer and cook 2 hours, stirring occasionally until meat is very tender. In another pot, saute the rhubarb pieces in 1 ounce of vegetable oil for 5 minutes. Add to the cooked beef, mix thoroughly and cook 10 to 15 minutes, until the rhubarb is soft. Squeeze the juice of $1 / 2$ of a sour orange or lemon into the stew and serve over rice.

Makes 4 servings.

If you wish, you may use a crock pot or pressure cooker. A pressure cooker will cook the meat in 30 minutes, after it has come to full pressure. With the crock pot, add water to cover the meat and cook according to crock pot directions for any meat stew.

\section{'Mayway nowrozee' (Fruits of the new year)}

2 ounces shelled almonds

2 ounces shelled pistachios

2 ounces shelled walnuts

2 ounces dried apricots

2 ounces dark raisins

2 ounces golden sultana raisins

2 ounces jujube fruit (dates can be substituted)

8 ounces heavy cream

In a bowl, soak the nuts with enough water to cover 3 inches over them, for 3 days. In another bowl, soak the fruits in the same manner. On the fourth day, remove the skins from the nuts and combine with the fruits. Put in individual serving dishes and pour 4 tablespoons heavy cream over each serving.

Makes 6 servings.

One dish, chapati, unleavened whole wheat and buckwheat bread, had Indian overtones. Everything else had a character of its own. The chapati was eaten with chaplee kebab, a spiced ground lamb patty popular along the Pakistani border.

The spice mix in the chaplee kebab is lawang, a typical Pashtoon or Tajik seasoning on the order of Chinese five-spice. Lawang consists of ground cinnamon stick, black cardamom seeds, black pepper, cumin and cloves. The condiment for the kebab was tundee, ground jalapenos, cilantro, garlic and onion.

While her guests sipped green gunpowder tea steeped with whole green cardamom seeds (delicious over ice, by the way), Parenti discussed other food customs of the culture. Cardamom is everywhere, she said. The green version is said to prevent gas and clean the palate.

"The green cardamom is in tea and desserts, the black is put in foods. To make the tea, put the seeds in water, bring to a boil and simmer five minutes, then add the green tea, steep three minutes, then strain off the leaves. Put it all, with the seeds, in a teapot. They drink tea after, before and during meals."

Another common beverage is yogurt, beaten into a liquid and spiked with dried spearmint, a little salt and pepper, and chilled.

Kebabs are served with a sort of salad on the side, scallions, cucumbers and plum tomatoes sprinkled with fresh lime juice and a little dried spearmint or fresh cilantro. 


\section{REEENT PUELIEATIONS}

"Musicians Who Do Not Perform: Performers Who Are Not Musicians: Indigenous Conceptions of Being an Afghan Musician" by Hiromi Lorraine Sakada in ASIAN MUSIC, Vo1. XVII, 1. Fa11-Winter 1985.

AFGHANISTAN IN THE WORLD PRESS, VOI. 1, 非 1 appeared in March 1986. It is a monthly magazine "which reflects the ideas \& opinions of press \& world personalities about the rightful jehad of the Afghan people" \& is edited by Dr. Sayed Moh'd Yusuf Elemi. Subscriptions are \$10/year from Post Box 417, G.P.0., Peshawar, Pakistan. Bank Acct. 非 649, Habib Bank Ltd., Cantt. Branch, Peshawar.

"Turning the Lights Out in Kabul" by Marin Strmecki appeared in DISCOVERY, a special supplement of HARVARD MAGAZINE, May-June 1986.

THE SOVIET INVASION OF AFGHANISTAN: A STUDY ON THE USE OF FORCE IN SOVIET FOREIGN POLICY by Joseph J. Collins, Lexington Books, Lexington, MA, 1986. 195 pp. $\$ 24.00$.

FULL TILT: IRELAND TO INDIA WITH A BICYCLE by Dervla Murphy was first published in 1965 \& has been reprinted this year by Overlook Press. It has a section on pre-Soviet-takeover Afghanistan. $235 \mathrm{pp}$. \$17.95.

THE PARTHIAN PERIOD by Malcolm A,R. Colledge (XIV/3 in the Iconography of Religions), Leiden, E.J. Brill, 1986. Xiv, 47 pp., 1 map, 48 plates. $\$ 35.75$. ISBN 9004071156 .

"Early historical Arachosia in southeast Afghanistan. Meeting-place between East \& West" by W. Vogelsang in IRANICA ANTIQUA 20, Leiden, E.J. Brill, 1985. \$42.50. ISBN 9004079009. (E.J. Brill, P.O.B. 9000, 2300 PA Leiden, The Netherlands.)

AFGHANISTAN: NON-ALIGNMENT \& THE SUPER POWERS by M.A. Wakman, Radiant Publications, India, 1985, 169pp. ISBN 0-391-03352-2.
WUFA, the Quarterly Journal of the Writers Union of Free Afghanistan: Vo1. 1, 非2, January-March 1986 contains the following articles: The Saur Revolution? by R. Rasul Amin, Muslims of Soviet Russia by Dr. Moh'd Anwar Khan, The Afghan Armed Resistance by Maj. Nasrullah Safi, Thru the Looking Glass: A Look at the Oficial Soviet Version of War in Afghanistan by Anthony Hyman, Report on the Massacres by Russian/Karma1 Forces in Nangarhar Prov. (1985-85) by Shamshad Kokozai, Refugee Syndrome by Dr. Moh'd Azam Dadfar, Afghanistan: A Sore Subject in the World Council of Churches by Dr. G.J. Winnink \& The Comrades at Arms? by Moh'd Nasim Shafq Stanizay. Subscriptions to WUFA are $\$ 20 /$ year from WUFA, P.O. Box 867, Peshawar Univ., Peshawar, Pakistan. Bank Acct. 非 1143, Habib Bank Ltd., Jamrud Road, Peshawar Univ., Pakistan.

Vo1.4, 非 4 of CENTRAL ASIAN SURVEY has 4 articles on Afghanistan: "The Conscription of Afghan Writers: An Aborted Experiment in Socialist Realism" by Nancy Hatch Dupree; "Afghanistan - Une Resistance Paysane: Almar, Nord Afghanistan" by Bernard Dupaigne; "The Russian Intervention in Afghanistan: The Economic War" by Sayd B. Majrouh; "Islam in Kabul: The Religious Politics of Babrak Karmal" by Chantal Lobato.

No. 3 of CENTRAL ASIAN SURVEY's Incidenta1 Papers Series is "Propaganda Posters of the Afghan Resistance, January 1985." Anthony Hyman has written the introduction to the pamphlet which shows 50 posters of the Internal Islamic Fronts Afghanistan. CAS publications are available from The Society for Central Asian Studies, P.O. Box 131, Oxford OXI 2 NJ England.

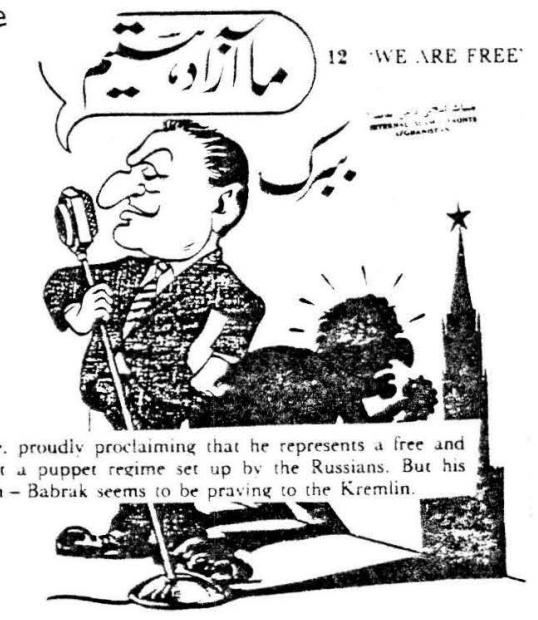


RUGS \& CARPETS FROM CENTRAL ASIA THE RUSSIAN COLLECTIONS by Elena Tzareva, translated by Arthur Shkarovsky-Raffe, Allen Lane/Penguin Books/ Aurora Art Publishers. 163 plates, 107 in color. Paper. \$19.95. ISBN 0140063692.

AFGHANISTAN: POLITICS, ECONOMICS \& SOCIETY by Bhabani Sen Gupta, Boulder, Lynne Reinner Publishers, Inc., 1986. 206 pp. \$25 (hard), $\$ 11.95$ (paper).

Publications of the Islamic Assn of Afghan Students \& Immigrants: In New York - TAKBIR, a monthly 3-page
(2 pages
in Eng-
lish)
per
year from P.0. Box 1369, Flushing, NY 11354. In Los Angeles - AFGHANISTAN JIHAD NEWS, a bi-weekly 4-page folder in English. Information from IAAS, P.0. Box 1946, Los Angeles, CA 90078.

NEW TREND, "An Independent Forum for the Oppressed Muslim Masses," regularly has articles on Afghanistan. It is available from the American Society for Education \& Religion, Inc., P.0. Box 356, Kingsville, $M D$ 21087. Subscriptions are $\$ 7.50 / \mathrm{yr}$ (overseas $\$ 13.50$ "a plain wrapper used on request"). 8 page tabloid format.

ETHNICITY, NATIONALISM \& THE PAKHTUNS: THE INDEPENDENCE MOVEMENT IN INDIA'S NORTHWEST FRONTIER PROVINCE by Stephen Rittenberg is being published by Carolina Academic Press in late spring. AFGHAN RESISTANCE: THE POLITICS OF SURVIVAL, edited by Grant M. Farr \& John G. Merriam, Westview Press, 5500 Central Avenue, Boulder, Co 80301, June 1986. \$19.50. Essays providing an interdisciplinary analysis of Afghanistan.

"Baluchistan: one refugee for every seven inhabitants" by Jean-Claude Pomonti in REFUGEES, May 1986.

\section{OTHER RESOURCES}

Slide set:

Early Buddhist Art of India and Afghanistan (2801)

This set includes the Mahabodhi temple at Bodh Gaya, its Mauryan "throne," and its ancient railing ( 10 slides); Kushan portrait sculptures, including Kanishka ( 9 slides); various well-known Kushan sculptures from the Mathura Museum ( 31 slides); the beautiful newly-discovered standing Buddha from Govindnagar, dated to 434 A.D. (7 slides); the colossal

Buddhas at Bamiyan and associated images (19 slides); and fine Buddhist sculptures in situ at Hadda (24 slides).

Order from ACSAA Color SIide Project, 150E Tappan Hal1, Dept. of the History of Art, Univ. of Michigan, Ann Arbor, MI 48109 (313) 763-0.517. \$130/set of 100 slides. Foreign ordeṛs - add $\$ 5.00$.

A NATION UPROOTED: AFGHAN REFUGEES IN PAKISTAN is a videotape available in hour \& $\frac{1}{2}$ hour version. A study guide comes with the tapes which are available for rental or purchase. Contact Denker/Mann Productions, 3006 S.E. Tibbetts, Portland, OR 97202. (503) 233-1694.

"Soviet Tactics in Afghanistan" by Vladislav Naumov in FREEDOM AT ISSUE, May-June, 1986

NOSHE DJAN. AFGHAN FOOD \& COOKERY by

Helen Saberi, Prospect Books Ltd., 45 Lamont Road, London SW10 OHU.

"L'Afghanistan" by Daniel Pineye in LA DROLE DE CRISE. DE KABOUL A GENEVE 1979-1985, Paris, Fayard, 1986.

NI PAIX NI GUERRE by Helene Carrere d'Encausse, Paris, Flammarion, 1986. 416 pp.

"Bombs, Bravery \& Banishment," a series of articles in INQUIRY magazine, June 1986, Vo1. 3, 非, looks at the Islamic struggle in Afghanistan. One of the 9 articles in the issue appears on p. 20).

AFGHANISTAN: AN AMERICAN PERSPECTIVE by JuIian $W$. Withere11, 非 3 in the Library of Congress Middle East Series, Washington, DC, 1986. This Guide to US Official Documents \& Gov't-Sponsored Publications is available from the Supt. of Documents, Gov't Printing Office, Washington, DC 20402 for $\$ 5$. (Stock 非 030-000-00174-5.) $160 \mathrm{pp}$.

AFGHAN REFUGEE RELIEF IN PAKISTAN: POLITICAL CONTEXT \& PRACTICAL PROBLEMS by Fazel Haq Saikal \& William Maley. Australian Defence Force Academy, Dept. of Politics, Univ. of New South Wales, Campbell ACT 2600, Australia. 


\section{BOOK REULEUS}

KABUL, a novel by M.E. Hirsh, Atheneum, NY, 1986. ISBN 0-689-11598-9. \$19.95.

Kabul is a novel full of bittersweet romances, head strong heros and enlightened revolutionaries, yet none of the characters afford the reader a sympathetic link to the novel. One does not expect a very accurate picture of Kabul since author M.E. Hirsh admits that she bases her novel on accounts by Afghan friends and not from her experience as she has never been there. The novel could just as easily have been called Moscow or New York since a great deal of the action takes place in those well described settings. Some of the best writing occurs when Hirsh captures the ambiance of these two cities. In Kabul, one neither feels transported to Afghanistan, nor part of the lives of the characters.

The story opens on the eve of both a wedding and Daoud's coup. Through a number of complicated digressions, the characters are introduced. The family, supposedly an extended one, is impossibly small by Afghan standards - perhaps because the . mother is American. Generally in pre-war Kabul families tended to be much more involved beyond the nuclear unit, even in their most intimate matters. Mohammed Anwari, the family patriarch, is a minister in the King's cabinet. He resigns on the day of the wedding because he has unearthed some corruption or, perhaps, has heard of the coup. His eldest son, Mangal, a Paris educated socialist, and new daughter-in-law Roshana, a Joan-of-Arc figure, on their wedding night agree to be part of "uncle" Daoud's revolution. Toryaly (Tor), the youngest son, is in love with a servant's daughter but cannot marry her because of the class difference. The book opens with Tor on his horse, riding in an attempt to relieve his anger. Tor's pouting demeanor persists throughout the book. His heart aches with resentment toward his elder brother, anger toward his sister and frustration over his ill-fated love. On the night of the wedding he gets drunk on his sister's brandy and reveals that she had an affair in the States. Sister Saria can now no longer expect to marry an Afghan or partake in the building of her nation the way her liberal friends and professors taught her in the USA. Her well-positioned brother Mangal finds her a job with the UN in New York where she falls in love with a Soviet diplomat, has another affair and betrays her country. Tor is exiled to Moscow.

The greatest difficulty with the book is that the characters do not develop. Throughout the book they remain as obstinant and self-centered as ever. It is unfortunate that Hirsh did not introduce an Afghan psychiatrist to work out their neuroses. Events unfold, but their personalities do not. Although much detail is accorded their personal lives, depth never graces any of their personalities. The characters never evolve to provide the reader with any kind of denouement beyond the irony of events. The historical background is basically accurate. However, when actual characters like Daoud are introduced the author takes much artistic licence. He is made to seem a highly social animal capable of convivial conversation which he was plainly not. He was known to sulk in corners at parties before becoming president.

The social atmosphere for women was not nearly as repressive as Hirsh depicts. Much acceptable socializing took place behind closed doors: Kabul University during the 70 s was filled with men and women socializing together; basketball games were cheered by chadori-less women. They did not, however, flaunt it. Roshana would not have gotten into as much trouble with her protests as Hirsh suggests. There were many working women, as well as institutions to help 
women pursue careers. The number of female doctors during the period Hirsh depicts was impressive.

Perhaps Hirsh tried to do too much. If one chooses to write about Kabul, then one should do research among typical families to capture the nuances of the city and its people. However, if one is attempting to relate the emancipation of Afghan women, rationalize socialism in Afghanistan, explain Moscow's repressive atmosphere for foreign students, cover the cultural conflicts facing a liberated woman in New York, as well as tell a story, one should probably consider a series.

I'm not sure what Ms Hirsh felt toward the Afghan friends who provided her with the background for the novel, but in Kabul Afghan families get a raw deal.

\author{
Laili Helms \\ New York City
}

KARA KUSH,: a novel by Idries Shah, Stein \& Day, New York, 1986. ISBN 0-8128-3098-9. $\$ 17.95$.

Kara Kush is the first novel about the war in Afghanistan written by an Afghan. It is Idries Shah's first novel (after over 30 nonfiction works) and was a best seller in Britain. Information for the book came from interviews, primary soviet sources, eyewitness accounts \& from Afghan legends, all of which are retold, some as specific actions and some as composites. The reality of Afghanistan seems to be so harsh and unbelievable that accepting the sources as reliable adds to an appreciation of the novel.

Although the characters are only superficially drawn, and little is said about the enormous refugee population, the story is one of events that are so remarkable and compelling that it sweeps you right along. Kara Kush is a strong adventure about Afghan nationality.

The main plot has Kara Kush, the "Eagle" (a composite of 3 guerrilla leaders), fighting 2 major battles - one in the northern port of Qizil Qala and one south in Kandahar - to rescue a legendary hoard of gold from the Russians. As the Eagle's army grows from 2 men to several thousand (of all ages and both sexes), different episodes are linked and paced to enhance the plot and reveal the breadth of the war.

The story includes: an English businessman who contributes himself and his fortune to the mujahideen; tribes living and fighting in the ways of centuries ago; deserters from the Soviet and Afghan armies who play critical roles in the success of Kara Kush's fighting force; an Arabian connection, as well as an Israeli one; and history, heroism and loss.

Two episodes in the middle of the book offer a change of pace that deepens the reader's understanding of the drive of the Afghans. In one, an innkeeper and his wife come to the aid of a woman fleeing Kabul. "Here was a total stranger, leaving his home and business, breaking the law, to take an unknown person into tribal territory just because she said she needed help." As they travel the innkeeper takes his place in the tradition of literature and history by telling stories that entertain and teach. The stories explain how the sacrifices of so many individuals are rooted in a code of fairness and honor. This code broadens one's sense of community and turns "sacrifices" into natural responses. In another episode, a middle aged linguist returns to Afghanistan to avenge the death of his nephew. Through his act of retribution we learn of the extensive communication network among the resisting population and how this avenger benefits that population 
unknowingly by the timing of his act.

Readily available nonfiction sources - notably Edward Girardet's articles and his Afghanistan, the Soviet War - support the image of the country depicted here:

"wild west" justice, physical bravery and luck pitted against misguided, selfserving invaders and exploiters.

The lingering impression is that when injustice is so clear, large and identifiable as that of the Russians, then acts of resistance will and should occur naturally and will be supported by cooperation, either by coincidence or design.

\section{Reviews from the KABUL NEW TIMES}

\section{WASHINGTON'S SECRET WAR AGAINST AFGHANISTAN}

by Phillip Bonosky, New York, Int'1 Publishers

(text printed in the USSR, cover printed in

$$
\text { the USA) } 19.85 .
$$

$$
\text { KNT } 5 / 6
$$
"Washington's Secret
Wit Against Afghanist-
an , written 'o the progr-
essive and realist Ameri-
can journalist, Phillip Bo-
nosky, is a compilation
of facts, figures, eye-witn-
ess accounts and objective
analyses. The views, co-
mments and perspectives
drawn by the author in
his search to find "the
reality that survives the
storm" enrich and enhan-
ce ones' understanding
of present-day Afghanis-
tan.

Reviewing briefly the glorious and eventful bistory of Afghanistan, Phillip Bonosky seeks to find the key to understand the on-going develo pments. Calling the triumph of the April Revolution (1978), led by the PDPA, a logical response to the long-cherished aspirations of the Afghan people, the author refutes the allegations and charges aimed at denigrating the historic significance of the revolution by giving it the appearance of a sudden or untimely phenomenon. "The fact is that neither the April Revolution, whis overthrew Sardar I'add, nor the December 27, :879 uprising, which overthrew Amin. was the work of a mere hanif il of adventurists withcu: popular support." (p. 73).

The book under review gives an in depth analysis of the CIA's notorious activities against the revolutionary movement in Afghanistan w. bich assumed the form of an ua. declared war right ath er the revolutior.. Quoti- ng an American official, this contest, history has using the pseudonym always chosen the side "Able Baker", the book of the creators and in threveals that the CIA's di- is very fact lies the eventrect intervention in Afg- ual total defeat of count. hanistan's interral affar er-revolution.

irs goes back a:s early as The book "Washingto the Daoud regine itsell n's Secret War Against (1973).

Phillip Bonork\%, a close observer and an sye witness to the growth nd consolidation of the re olutionary process in Afghanistan, exposis the desperate atten if of the Afghan counter . :evolut. ionariea maiturminaed by the CIA to bring back the feudal social relat. ions. Hereby he comes, as any other unbiased pe rson should come, to the conclusion that while co unter revolution worked to tear down, the revolution worked to create. In Alghanistan" in the seres of tens of books, pamp blets, brochures, etc., Written by objective and 30 berminded Western writers and journalists, among others, can and shou1d play its role in tearing apart the smokescreen of lies and forgeries crested by information imperial ism about the situation in and around Afghanistan. The truth, in the long run, will triumph over falsehood and fiction, no matter how the latter resist.

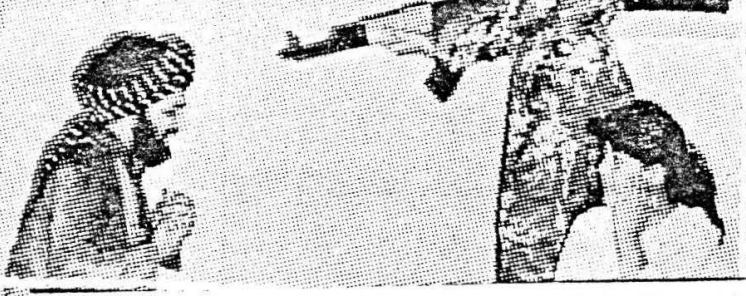

A scene from the play 'Masks Fall Down'.

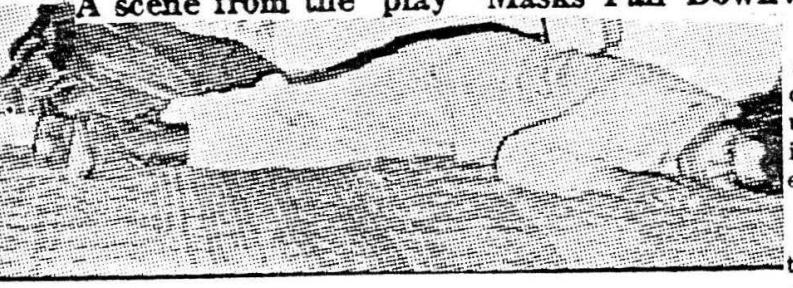

\section{"Tiger" and}

\section{"Masks Fall bown"}

Theatre-e-Guli-Surkh (Red Rose Theatre) of the DYOA, presented "Tiger and "Masks Fall Down", two plays, on the stage of the House of Soviet Science and Culture in Kabul, recently. Both plays are dedicated to the 10th founding anniversary of the DYOA.

The script writer and stage director of the "Masiss Fall Down" is Ahmad Shah Salik, also a talented actor of the Red Rose Theatre. The play tells story of a valiant soldier who fights for his homeland and Revolution. $\mathrm{He}$ is injured in a lace to face fight with counter-revolutionary bandits. He becomes a martyr.

His brother Tahir, who has close links with bandits and committed many crimes returns home to find his brother killed. This arouses his dead conscience and he laments over his brothers' death Tears of remorse fall from his face and he refrains from his past deeds. But his sister puts on her soldier brother's uniform and picks up his gun She seizes the treachero us brother and turns him ver to the law.

"Tiger" a homorous comedy touches upon one of the most sensitive isoues of youth, i.e. enrolling in the ranks of the armed forces.

During performance of the comedy, the audience often explodes with laughter.
Tahir Rasul plays the part of Palang or 'Tiger'. influenced by the nasty propaganda of counterrevolution, his family forbid him from joining the army.

The young but nearly half-mad son of the tomily, incidentally gets away from home and voluntarily joins the army ranks. Sool he became literate and writes to his family. Dressed in bis uniform some time later he retums home. His ta ther embraces him with astcrishment.

His fiancee who had been fed up with his previous deeds and even ta ken the decision to give him up immediately agrees to be his bride.

Ahmad Shah Saltk Tahir Rasul, Fahima Sh erzai, Farica Famrah, Raz. M. Baghban, Wahidullah Kawyar, Asmatullah and Humayon, ver. satile and energitic actors of the Red Rose The atre bave created the characters very expressively.

Besides, two short items of mimicry are also included in the plays, as a happy and sensational ending. These two pieces are performed by Raz. M. Malik Husain and Zaimai.

Red Rose Theatre still being in it's initial st age, has acquired reputation among theatre $g^{\circ}$ ers. Artists of the theatre by their few performances have already won the hearts of the Kabul public.

$6 / 2$ 


\section{"THE LAND" " wer slo}

Screenplay and direction: Jalal Peruz.

Photography:

Ramaq.

Cast: Qadir Farukh, H2shmat Fannahi, Huma,

Tajzoi and...

Production: Alghan

Film.

"The Land" based on a realistic story, is the title of a black-and-white feature film which is now being produced at the studios of Afghan Film.

The =hoct: 5 of "The Lanci. vegan on Aprii 1 , and it is expected to be released in Kabul movie theatres in three months time.

"The Land" tells the tr-

ue story of the land ref- orm in a remote hamlet of the country. The class struggle between land lords and peasants and the revolutionary life of our people, are the main essence and theme of the film.

The fiim in its first part features the life and attempts of the Malik (landowner and elder of the hamlet, who does everything for exploitation and to serve his interests in the hamieri.

When Malik bears of the victory of the democratic and national revo lution, he tries his utmost. to continue holding to the land and peasents under him. He
By A Stalf Reporter and his lackeys commit bloody deeds to block the proceedings of the progressive land reforms, and to prevent his own land being distributed. At the same time Malik and his men fail to block the land reform, he receives a letfrom a bandit group. The head of the armed group promise Malik, weapons and help to disturb the security of the hamlet.

Nader, head of the bandit group. who changed his name and became oseutio-lergy sends weaFnns and some counterrevolutionary elements to support Malik, and later netumself joins the band of Malik.

The head of the local cooperatives of the peasants and some elementary school teachers, fall the first victims of the murderers.

Towards the end of the film, a close mercenary of Malik finding so many killings and subversive activities, against his own people, avoids orders of Malik and kills Malik.

The death of Malik changes into a real jubilee of peasants and all people of the hamlet. The role of Nader is played in the film by Fasnuat Fannahi, = versatile actor who gaints fame long ago for his acting talent. Hanüaüi isas unique talent and strength, in playing a multitude of the characters.

"I think an actor must be truthful and convinc ing in any character" says Hashmat when he read the script, he chose the role of Nader and the Director of the film also agreed.

Hashmat attended Kunduz Nandary (provincial theatre of Kunduz), 12 years before. Then he came to Kabul and joined Ariana film industry, and after 1980 , he began working at Afghan Film organiz-nt:n ns an artnr. Fe has acieci in more than 8 full length feature films.

\section{Spring \\ sunshine in}

We set out for the for explain. o the ares of orchards and the Presidium of the vine-yards of Shamali, Revolutionary Council a place of gardens of on the remission of tax could bring warmth and delight to the bearts of the visitor. In these spring days, the peasants are busy workdng with enthusiam, on their lan ds and in the vine-yarda of Sharnali. They work hard. For, the comfort and tranquillity of their tomorrow is linked wi th their txay's hard work and truggie.

Thanies th the revolution, these nce exploited people are now on llicting what they grow an their land wich the received after the revo lution. And, the reralu tonary state bas spared no asistance or facllitie to them, thus enablin them to raise their livin

standards and increase their yields. And so the working peasants and worklng peasants and than ever before in orde to collect more.

When I reached the bazar of Mirbachakot district, I met crowds of people, including peasants craftsmen, school children old and young people who are going to the district. Epic so ngs are heard from the administrator's c....t. re are toid tna 4 ineeting would be held today in Mirbachakot di strict of Kabul orovin- penalty

All those who are go ing to the meeting seem happy and these are lively talks and exchanges. They know that the decree is directly linked with their life Every one of them is in a hurry to reach the meeting place.

Chairs are put in regular rows and slogans on land reform, cooperatives and other issues aftecting the lives of peas ants are displayed in the compound of the district administrator's office. There is a continuous flow of people to om among them I stopom a stopwaja Ghulam kan village and asked xan village and asked whe new decree.

He said: "Brother, I cannot speak in the lit erary style, but in simple and in the way of peasants. Since the reyolution triunphed in ou country. every ineasur of our revolutionary state has been infavou of landless and smallland-holding peasants. Every type of assistance is rendered to us. Che mical fertilizers improved secdis are give to us on loan basis. This to us on loan basis. This is the second time that tax penalty. In 1359 HS the office compound

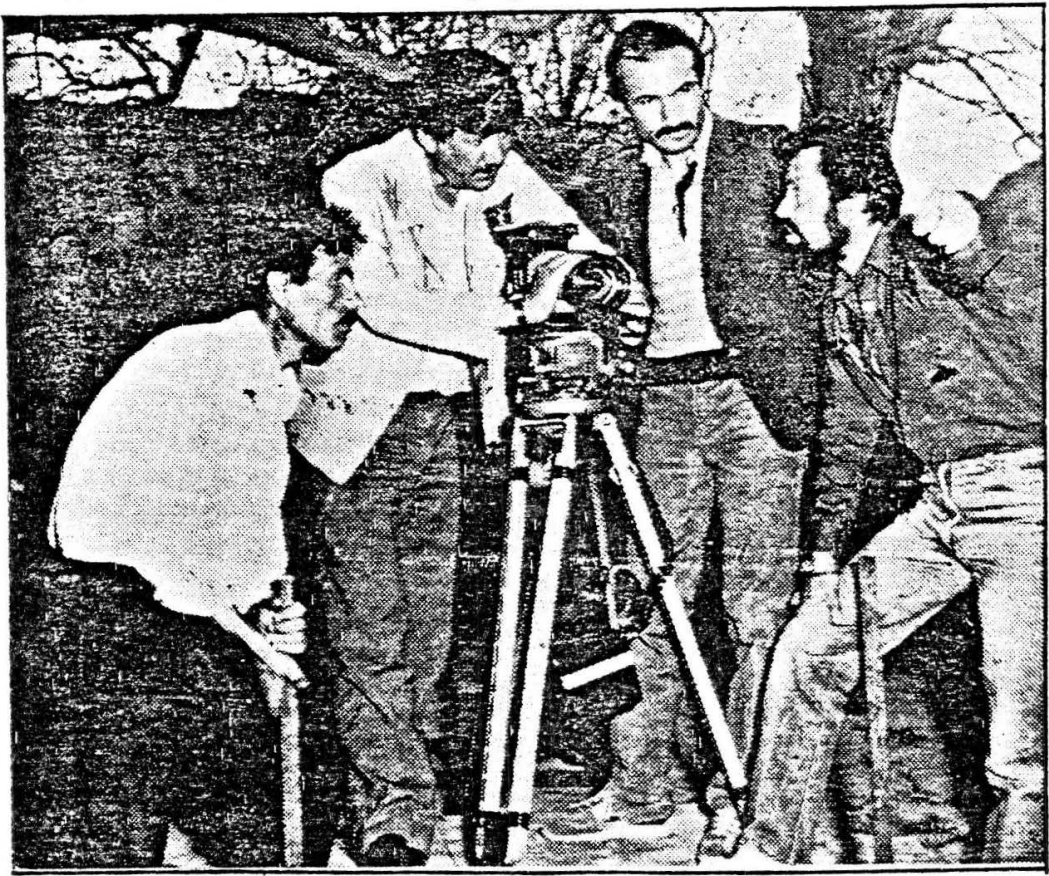


the tax penalty of years
1357 to 1359 HS. Was pardoned by the state and now the second remiss ion covers the period from 1360 to 1364 HS.

which we owe by the The announcement of the function interruptc our talks.

First, a mullah recited

"I myself have eight jeribs of land and have not paid the tax on my land during these five years. I was fined to pay around Afs 3,000 But, it is because of the mer,: it is because of the mera: of our comipassionat. governmer:. that 1 was exampte - from the payment. And I am going to pay, with pleasure, the tax on my land in instalment and complete the payment by the end of this year. $\mathrm{Li}$ ke, many peasants of our village were fined at all them have been exempted from pavment. And all of us have resolved to pay the tax verses from the holy Quran. Then, the decree of the Presidium of the Revolutionary Council on waiving the tax penalty was read out Speakers dweit on the assistanc given by the revolutionary state for improvin the living standards of peasants and the state plans in providing facplans ities for peasants a explained the decree... I chatted with a man holding a list in hand His name is Abdul Manan and he is head of the astricultural coopera tive of Guzarmiwa Kh aton village. He came

here to get chemical fe- 
We talk of a city that has traversed a long way in history, a city that witnessed great events and carries the flame of revolution in its heart.

There are 2500 historical relics in Herat. One can hardly decide what to see first. Let us begin at the Jama Masjid or Grand Moscue of the ciby. Long ranks of wor: snipers who have come to pray draw our attention. Mullahs and patriotic spiritual figures at the end of the service speak about justice, brotherhood, equality and cooperation and assistance to their neighbour and working people. In the city one's attention is attracted by shops and markets all well stocked with food stuffs and other essential needs of the people. Prices are reasonable. Some having done their shopping are returning home with goods while others still bargain with the shop keepers for cheaper prices.

I find myself in front of an Ironsmith's shop, whose young apprentices beat a mase of red-hnt imn with thoir hoary hamm. ers reducing it to a flat shape. A little farther, there is another shop, be longing to Lal Mohammad. The walls and ceiling of the shop are painted, beautifully. Jugs and other containers and pots are arranged in an orderly manner.

One of the pots is more attractive than the rest. It is in fact an aquarium with onld fich flnsting in crystal clear water. Pleasant Afghan music is heard in the shop. I began to chat with the shopkeeper who says: "Thank. God, this year is a prop- itious one. For, there has been several snow falls and we don't have to worry about drought. The prices of food stuffs and other goods are coming down each day." Laying his hands on a great barrel of rice he says.

"This is the high quality Syawashani rice. Its price is 380 Afs. per ser (seven kilos) You see how fine it is cooked, it feels like silk. Others standing around me confirm his words.

Ahmadullah, dhother shopkeeper says:" There is abundant quantities of flour, cheaper than in Kabul. Meat and fruits are also sold at reasonable prices. Nothing is expensive in Herat city."

There are crowds of people every where. Law and order are maintained and tranquility and security prevail all over the city.

Next, I made a trip by car to the military headquarters of Herat. There was heavy traffic on the roads. Througt ise strects were not in good condition, there was no dust from passing vehicles. For, the streets are sprayed with water every morning. and evening. At the hall of the headquarters, I had a talk with Imtiaz Hassan, member of the PDPA $C C$ and secretary of the Party provincial committee of Herat province. Concerning the general situation in Herat and consolidation of the social pillars of the revolution, he says:

"The situation is improving in Herat day after day. You must have visited the city before. Co- mplete tranquility prevails all over the city. We are trying to ensure the situation as it is. In the districts and subdistricts too, the people are engaged in their peacefully occupations. Desnite tho desperate efforts of the counter - revolutionaries, order is maintained in all administrative units of the province (12 district and 3 subdistricts) and with each day that passes it is getting consolidated. The ranks of the party have strengthened and the Jirgahs are expanding. Right now, the re are 69 permanent Jirgahs (councils) in the province of which, five are functioning in the districts and settle the problems of the people. The democratic youth organisation and organisations of pioneers actively carry on their duties with 3754 youth and 5000 pioneers enrolled re spectively. The members of our provincial committee carry on "their $\mathrm{mi}$ ssions along with the publicity groups to the farthast refions vi the province on the basis of the predetermined grograms, and explain the objectives of the party and the state to the people.

Recently in an attempt to explain the ten-point theses of Babrak $\mathrm{Ka}$ rmal, General Secretary of the PDPA CC and president of the RC of the DRA was made and in the meetings and rallies we had lot of discussions with the people. We intend to continue the series of talks. We tound that the people fully support the theses of Babrak Karmal. During , this trip we were accompanied by the medical personnel of the friendly fo- rces of the USSR who treated patients. The people warmly welcomed their humanitarian action.

The governor of Herat province while speaking about the inflow of misguided Afghans from abroad said: "The return of the deceived compatriots from Iran is continuing and their number has increased, parcicularly after they got to know about the ten-point theses of Babrak Karmal.

There is a special commission duse duty is to supply first aid, to the returnees, to solve their problems and to admit their children to schools.

Col. Ghulam Sakhi Atmar.

\section{National}

\section{aclas to be}

published :

$$
\begin{aligned}
& \text { RABCL, (BIA).- } 1 \\
& \text { The national atlas of } \\
& \text { KNT } 6 / \%
\end{aligned}
$$




\section{Comrade Najib}

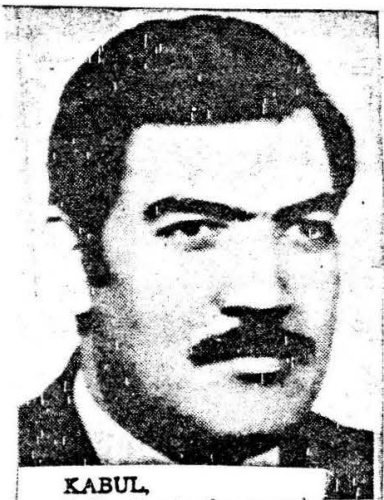

Following is the speech of Comrade Najib, General Secretary of the PDPA Central Committee delivered in the 18th plenum of the PDPA CC.

Esteemed comrades of the Politbum and mem bers of the PDPA Central Committee !

With due respect to the services of esteemed Ca mrade Babrak Karmal, rendered on the path of founding. strengthening and growth of the party and growth of the party April Revolution, permit me to express before you, esteemed comrades, my most sincere and warmest gratitude for the great $t r$. ust laid in me in electing me as the General Secretary of the PDPA Central Committee. I shall preserve it as the pary's ho nour and most loftiest $t r$. ust laid in me.

I perceive the gravity of this great responsibility entrusted by you, comrades, on my shoulder with all its dimensions. assure you, comrades and pledge belore you that shall endeavour, as a simple soldier of the army of my party by relying on the collective will and wisdom of party members, its Central Comm ittee and Politburo, to realise the aspirations an objectives of my beloved party and the April Revolution, with undeviating observance and precise employment of tested progressive and revolution ary principles which have shown us the legality and the course of revolutionary struggle and construction of a new society and defined the ways and means for achieving them under the present conditions of our country. I shall constantly pursue the goiden line of the bome and foreign policies of the People's "Democratic Party of Afghanistan and the state of the Democr. atic Republic of Afghanistan, and will spend all my energy, might wisdom and knowledge on this path.
I will carry out the strengthening of unity and solidarity of the raniks of iny party as the loftiest task and dedicate all $\mathrm{my}$ efforts for its realisation. Unity of thought and action of party members is the great force and guarantor of the victory and eleyation of the leading and directing role of our party.

Our party will continue in an undeviating and consistent manner, the implementation of the decisions of the $16 \mathrm{th}$ and 17th plenums af the PDPA Central Committee and the 10-Doint theses endorsed by the Revolutionary Council alo$\mathrm{ng}$ with the mobilisation of all factors in accelerating, expanding and strengthening the social pilars of people's revolut. ionary power and in providing possibilities and ensuring the active part icipation of workers, peasants, craitsmen, intell. igentsia, private entrepreneurs, national trader clergymen, women, you th and representative of all nationalities, tribes and ethnic groups of the country in social and ste ate at's.urs.

Comrades

Strengthening of the armed forces of the DRA and elevation of their combat capability are at the top of the tasks of the party and the state for accelerating the struggle against the undeclared war in the country and stopping the bloodsace and tranquillity the homeland.

Eve: further strengthening and many-sided enriching of our friendship with our great neighbour, the Soviet Union, the party of great Lenin and the heroic, sincere and $c o$ mpassionate people of USSR still constitutes the base of our work. The $\mathrm{Pe}$ ople's Democratic Party of Afghanistan shail pursue in a consistent and undeviating manner, its friendship and cooperatirn urith fratemal park ies, and socialist countries. and consolidate it friendly relation non-aligned countries and non-aligned countries and
all parties and organizations that fight for peace and progress of the humankind.

The prevailing situation and conditions urge every one of us and all party members to actively work and struggle, with revolutionary optimism, new apprasch and understanding of the necessity of new-type of work love for working man and sense of servin the people and how.: under the banner of our
Comrade Babrak Karmal's proposal

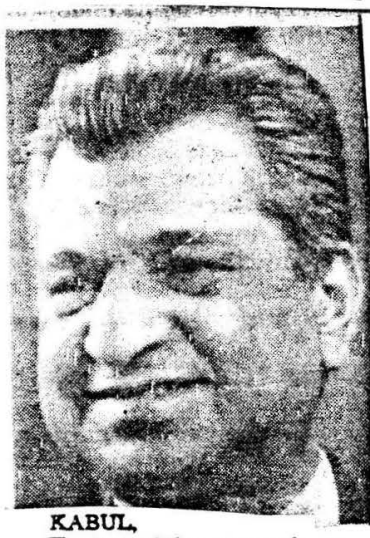

ple and my prideful and. at istan.

At this moment I believe that the leadership of the PDPA would elevate the best prideful and ber. oic traditions of our party $I$ invite all my perty comrades to bonour the unity of the party ranks as the pupils of their eyes and to preserve it and to respect the unity and solidarity of the party, the unity of all the peoples, ethnic groups, tribes and nationalities of our united country, dear Arghanistan on the basis of the equnlity of rights witb revolutionary and patrio tic and internutionalist spirit.

With patriotic love and of Comrade curak Karmal on bis being relieved from the post of General Secretary of the People's Democratic Party of Afghanistath to the Central Committer of the PDPA reads as follows: Comrades:

In view of my sense of esponsibility, health sons, accurate assessment of my possibilities and giving consideration to in. ternational problems inter much contemplation I ter much contemplation. I decided to request you to excuse me trom the post of General Secre

Awaiting your positive decision, I would like to express my thanks to my party comradie-in-arms including the leadership cadres and the ranks who cooperated in most difficult years of struggle and revolution for the strengthening of party's ranks in a collective and sacrificing manner.

All of my conscious and dedicated life bas beon devoted to the party, revolution, the working and

honourable Afghan peo.

beloved party, for reall ing the lofty and bumen aspirations of the PDPA and the April Bevolution.

While expressing hear ty thanks to the warm and cordial assertions of Com :ade Sultan All Kent. mand representting the $P_{0}$ litburo of party, I once equin express grattude tor the sincere on yourt comrer dentand of you comre tral Commite and its Politures all party nembers thet I will sper ad all mo mint and ene ro tor the great eave in order to make mysels deacrive the great trust laid $b$ me

KNT 5/5

rugale based on revalub lonary theary and the wa ptation to the spectelc hh scorical conditioces of the country for ensuring pear and propertty of the wo ting and bonourable Afhinn people construetion o new revolutiouary Af Dew revolutiouary jon of eresturther unit of the party and the final victory of the April Revalution.

I acertice my life and blood for the prosperity of the people and our beloved country, the new and revolutionary Aighanistan.

KNT $5 / 5$

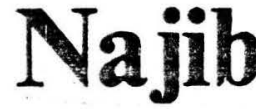

Comrade Najlb was boen in the year 1947 in the family of a government official. He is Pahitoon by nationality. Coinrade Najib graduated in 1964 trom Habibia Hilgh Sch$\infty$ and firisined bis bigher studies in the frculty of medicine, Kabul University in 1975.

Comrade Najib brecame a member of the Peop le's Democratic 'a ty of Afghanistan in (1865)...

Comrade Najib from 

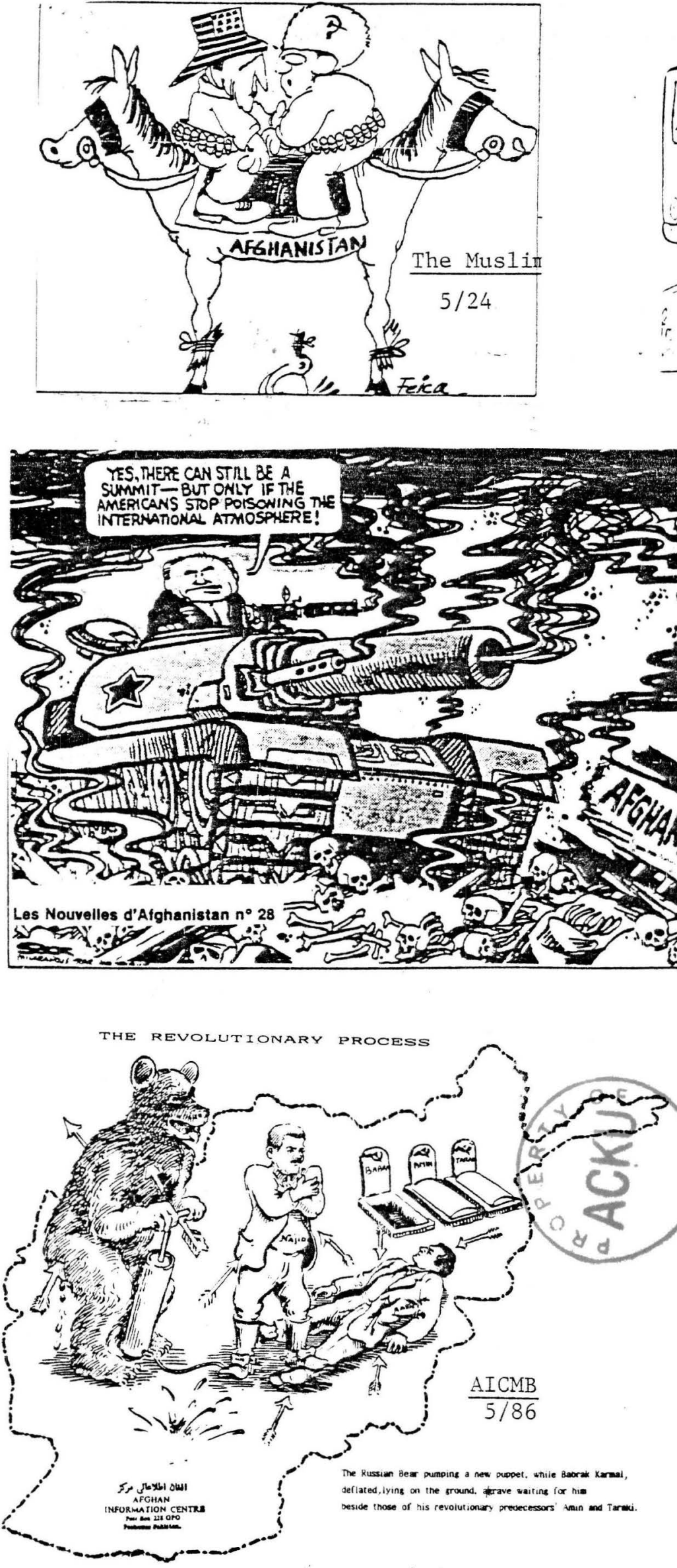
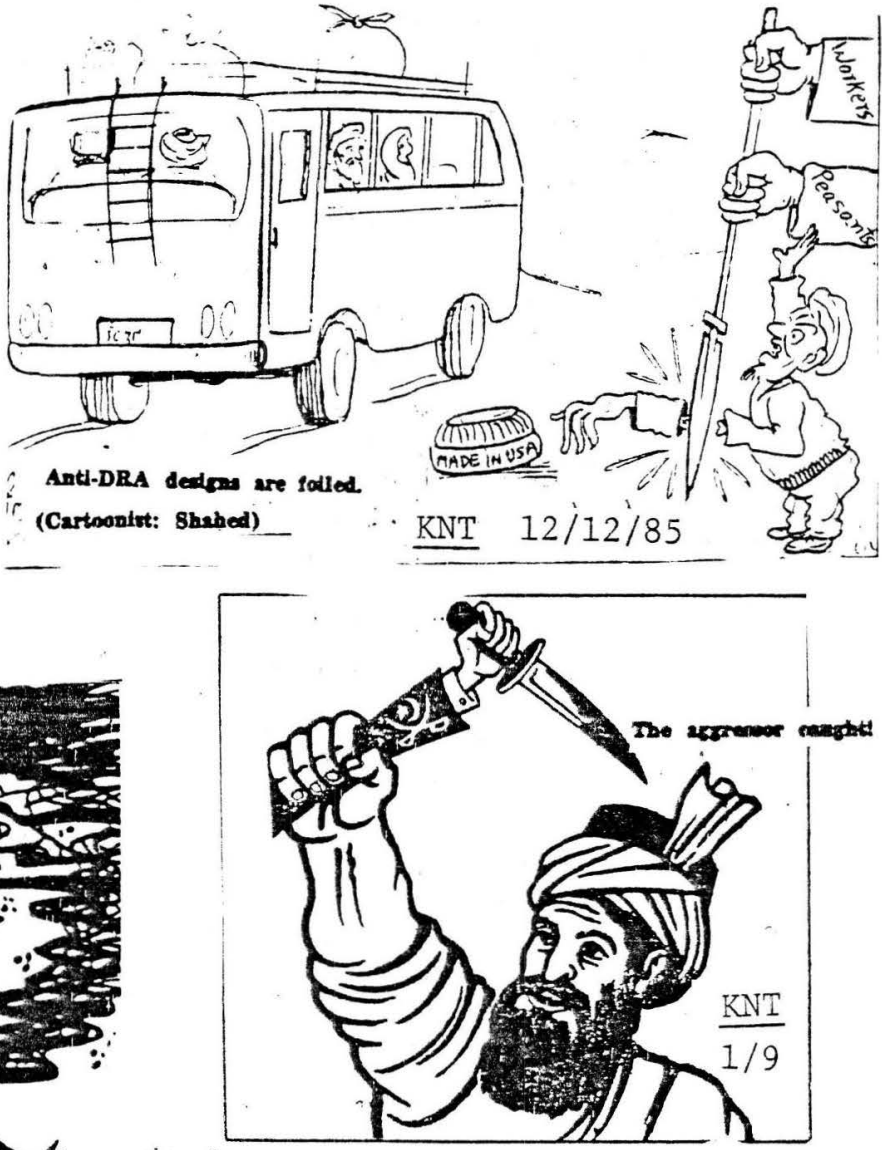

KNT $10 / 30 / 85$ Ny (12) $\% / \%=60$ 